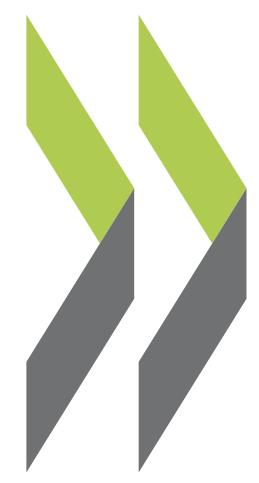

OECD Economics Department Working Papers No. 1223

Finance and economic growth in OECD and G20 countries
Boris Cournède, Oliver Denk 
Organisation de Coopération et de Développement Économiques

Organisation for Economic Co-operation and Development

16-Jun-2015

ECONOMICS DEPARTMENT

English - Or. English

\section{FINANCE AND ECONOMIC GROWTH IN OECD AND G20 COUNTRIES}

ECONOMICS DEPARTMENT WORKING PAPERS No. 1223

By Boris Cournède and Oliver Denk

OECD Working Papers should not be reported as representing the official views of the OECD or of its member countries. The opinions expressed and arguments employed are those of the author(s).

Authorised for publication by Jean-Luc Schneider, Deputy Director, Policy Studies Branch, Economics Department.

All Economics Department Working Papers are available at www.oecd.org/eco/workingpapers

JT03378727

Complete document available on OLIS in its original format

This document and any map included herein are without prejudice to the status of or sovereignty over any territory, to the delimitation of

international frontiers and boundaries and to the name of any territory, city or area. 
OECD Working Papers should not be reported as representing the official views of the OECD or of its member countries. The opinions expressed and arguments employed are those of the author(s).

Working Papers describe preliminary results or research in progress by the author(s) and are published to stimulate discussion on a broad range of issues on which the OECD works.

Comment on the Papers is invited, and may be sent to OECD Economics Department, 2 rue André Pascal, 75775 Paris Cedex 16, France, or by e-mail to eco.contact@oecd.org.

The statistical data for Israel are supplied by and under the responsibility of the relevant Israeli authorities. The use of such data by the OECD is without prejudice to the status of the Golan Heights, East Jerusalem and Israeli settlements in the West Bank under the terms of international law.

\section{(C) OECD (2015)}

You can copy, download or print OECD content for your own use, and you can include excerpts from OECD publications, databases and multimedia products in your own documents, presentations, blogs, websites and teaching materials, provided that suitable acknowledgment of OECD as source and copyright owner is given. All requests for commercial use and translation rights should be submitted to rights@oecd.org 


\section{ABSTRACT/RÉSUMÉ \\ Finance and economic growth in OECD and G20 countries}

This paper shows that finance has been a key ingredient of long-term economic growth in OECD and G20 countries over the past half-century, but that there can be too much finance. The evidence indicates that at current levels of household and business credit further expansion slows rather than boosts growth. Causality from more credit to slower growth is supported by a novel empirical methodology which exploits changes in financial regulation across countries and time as a source of exogenous variation in financial size. The empirical analyses point to five factors that link more credit to slower growth: $i$ ) excessive financial deregulation, ii) a more pronounced increase in credit issuance by banks than other intermediaries, iii) too-big-to-fail guarantees by the public authorities for large financial institutions, $i v$ ) a lower quality of credit and $v$ ) a disproportionate rise of household compared with business credit. By contrast, expansions in stock market funding in general boost growth.

JEL classification: G1; G2; G3; O41; O47; O57.

Keywords: Finance, GDP growth, economic growth, OECD countries, G20 countries, intermediated credit, financial regulation, too-big-to-fail guarantees, debt finance, equity finance, household credit, business credit, bank credit, capital-market credit, stock market.

\section{Finance et croissance économique dans les pays de l'OCDE et du G20}

Ce document montre que la finance a été une composante essentielle de la croissance économique à long terme dans les pays de l'OCDE et du G20 durant les cinquante dernières années, mais que parfois, il peut y avoir trop de finance. Certaines observations montrent en effet qu'au niveau actuel du crédit aux ménages et aux entreprises, toute nouvelle expansion freine plutôt qu'elle n'accélère la croissance. Des liens de causalité entre l'accroissement de l'offre de crédit et le ralentissement de la croissance sont mis en évidence par une nouvelle méthode empirique, qui utilise les modifications de la réglementation financière dans les pays et dans le temps comme une source de variation exogène de la taille de la finance. L'analyse empirique attire l'attention sur cinq facteurs qui établissent un lien entre l'accroissement de l'offre de crédit et le ralentissement de la croissance : $i$ ) une déréglementation financière excessive, ii) une émission de crédit par les banques en progression plus rapide que par les autres intermédiaires, iii) les garanties des pouvoirs publics sur les établissements d'importance systémique (TBTF), $i v$ ) une moindre qualité du crédit et $v$ ) une augmentation du crédit aux ménages nettement plus forte que celle du crédit aux entreprises. En revanche, l'accroissement du financement par actions en général stimule la croissance.

Classification JEL : G1 ; G2 ; G3 ; O41 ; O47 ; O57.

Mots-clés : Finance, croissance du PIB, croissance économique, pays de l'OCDE, pays du G20, crédit intermédié, réglementation financière, garanties des pouvoirs publics sur les établissements systémiques, financement par l'emprunt, financement sur fonds propres, crédit aux ménages, crédit aux entreprises, crédit bancaire, financement sur les marchés financiers, marché boursier. 


\section{TABLE OF CONTENTS}

FINANCE AND ECONOMIC GROWTH IN OECD AND G20 COUNTRIES …....................................

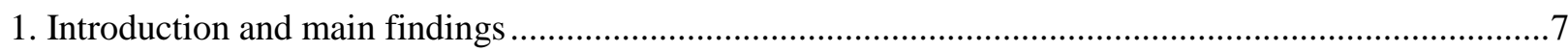

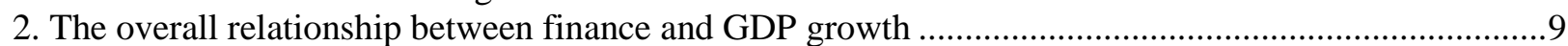

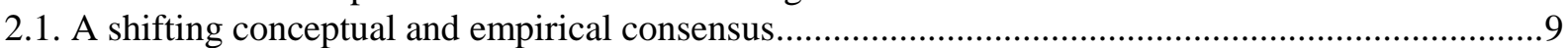

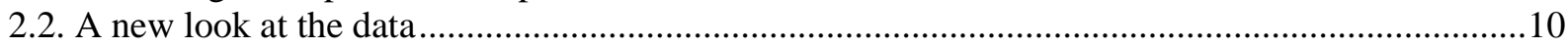

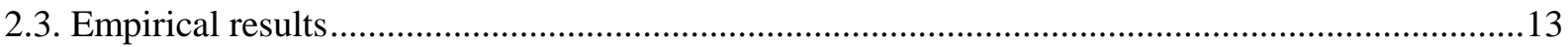

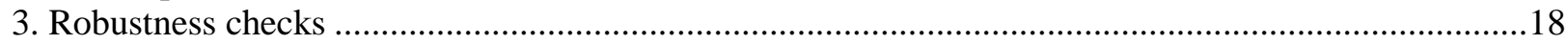

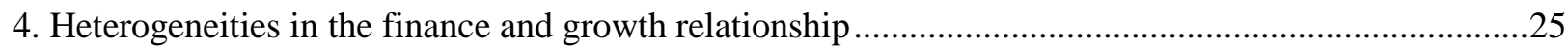

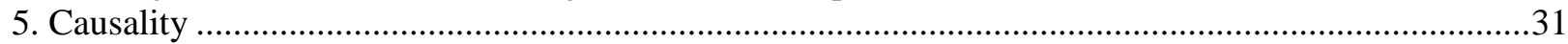

5.1. Mapping the effect of financial deregulation on financial size ....................................................32

5.2. Taking a new approach to evaluate the causal effect of finance on GDP growth ............................38

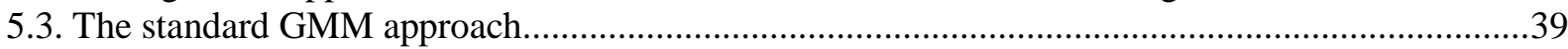

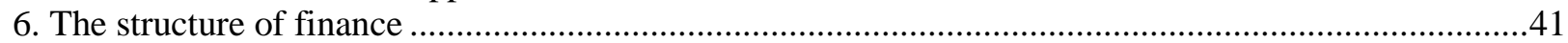

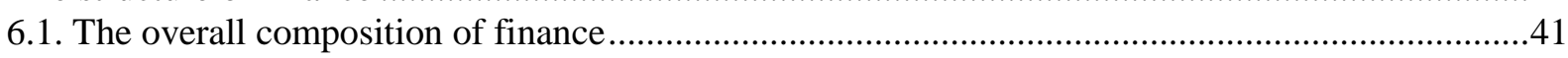

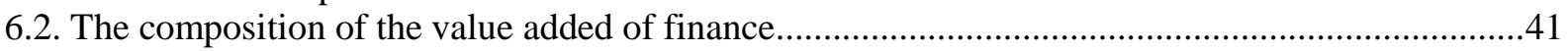

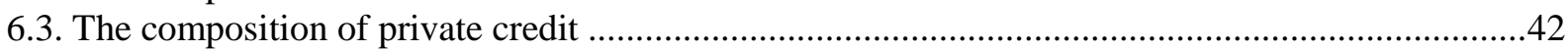

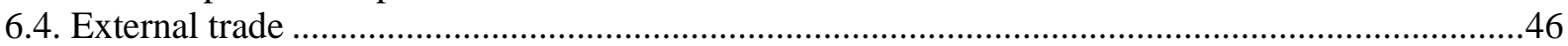

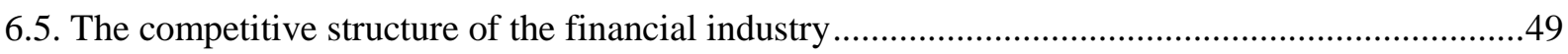

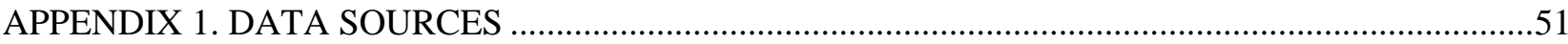

APPENDIX 2. CAPITAL SURCHARGES TO INTERNALISE PUBLIC GUARANTEES FOR TOOBIG-TO-FAIL BANKS: A SIMPLE CALCULATION .......................................................................52

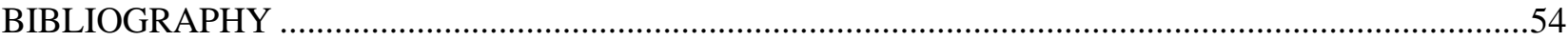

\section{Tables}

1. The relationship between the value added of finance and GDP growth per capita .............................15

2. The relationship between intermediated credit and GDP growth per capita.......................................16

3. The relationship between stock market capitalisation and GDP growth per capita .............................17

4. The role of consumption and trade for the finance and growth relationship .....................................19

5. The relationship between finance and growth of potential GDP per capita........................................20

6. The relationship between finance and GDP growth per capita using five-year averages .....................21

7. The role of innovation for the finance and growth relationship............................................................23

8. The role of the labour share for the finance and growth relationship ..............................................24

9. The finance and growth relationships for individual OECD and G20 countries ...............................26

10. Testing for a quadratic relationship between finance and GDP growth per capita ...............................27

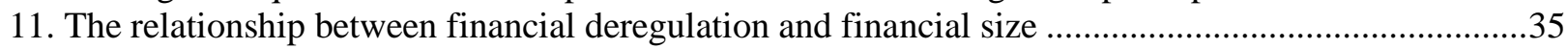

12. The causal effect of finance on GDP growth per capita: The first stage ..........................................37

13. The causal effect of finance on GDP growth per capita: The second stage .........................................40

14. The relationship between the structure of finance and GDP growth per capita.................................42

15. The relationship between the structure of credit and GDP growth per capita ....................................44 
16. The role of trade in financial services for the relationship between the value added of finance and

GDP growth per capita.

\section{Figures}

1. The bivariate relationship between the value added of finance and GDP growth per capita.................11

2. The bivariate relationship between intermediated credit and GDP growth per capita..........................11

3. The bivariate relationship between stock market capitalisation and GDP growth per capita ................12

4. The varying association between the value added of finance and GDP growth per capita ..................28

5. The positive then negative association between intermediated credit and GDP growth per capita.......29

6 . The positive then negative association between stock market capitalisation and GDP growth per capita

7. Intermediated credit and stock market capitalisation in OECD and G20 countries.............................. 31

8. The bivariate relationship between financial deregulation and the value added of finance ..................33

9. The bivariate relationship between financial deregulation and intermediated credit.............................33

10. The bivariate relationship between financial deregulation and stock market capitalisation .................34

11. Ratio of domestic consumption to domestic production of financial activities .................................47

12. The role of trade in financial services for the bivariate relationship between the value added of

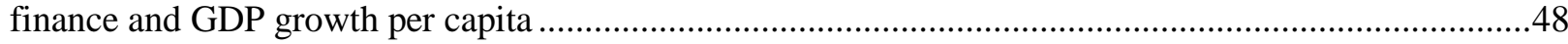


ECO/WKP(2015)41 
ECO/WKP(2015)41

\title{
FINANCE AND ECONOMIC GROWTH IN OECD AND G20 COUNTRIES
}

\author{
Boris Cournède and Oliver Denk ${ }^{1}$
}

\section{Introduction and main findings}

1. Deeper financial development, financial innovation and cross-border financial integration were until recently seen as bringing greater efficiency and stronger economic growth. However, the Great Recession, which has led to large losses in output and employment in many countries, has raised questions about the influence of finance on economic activity. Indicators measuring financial size, for instance credit intermediation or stock market capitalisation, have risen enormously over the past half-century. Similarly, the structure of financial activities has undergone a profound transformation. One example is the big shift in the destination of private credit from business loans to mortgages. These secular changes to the financial landscape have taken place during a period in which trend economic growth has slowed down in many countries.

2. This paper revisits the long-term relationship between finance and GDP growth in OECD and non-OECD G20 countries. It uses panel data econometrics to investigate whether rising finance and slowing growth are merely coincident trends or have a deeper connection. The paper also studies the effect that changes in the structure of finance and the emergence of international financial centres have had on economic performance.

3. The links with GDP growth are studied for three measures of financial size: $i$ ) the value added of finance, $i$ ) credit by banks and similar institutions to the non-financial private sector and iii) stock market capitalisation, in each case relative to GDP. GDP growth per capita is regressed on the financial indicators, while controlling for standard growth determinants, country fixed effects and year fixed effects. Although a wide-ranging literature has analysed the finance and growth relationships, the primary contributions of this paper are: $i$ ) a particular focus on advanced countries, $i i$ ) the inclusion of data since the global financial crisis, iii) the development of a novel empirical methodology to determine the causal effect of finance on growth, and $i v$ ) new and comprehensive evidence on the way the quality and structure of finance influence the overall finance-growth nexus.

1._Economics Department, OECD. Email: Boris.Cournede@oecd.org and Oliver.Denk@oecd.org. This paper is part of the OECD project "Finance and Inclusive Growth" that was prepared for the Working Party No. 1 of the Economic Policy Committee. Earlier versions of the paper were discussed in meetings of the Working Party and seminars of the Economic Development and Review Committee and on New Approaches to Economic Challenges. The authors would like to thank the participants for their feedback. They are also grateful to Sebastian Barnes, Adrian Blundell-Wignall, Romain Bouis, Lorenzo Codogno, Alain de Serres, Sean Dougherty, Alberto Gonzalez Pandiella, Antoine Goujard, Jonathan Greenhill, Stéphanie Guichard, Peter Hoeller, Christian Kastrop, Catherine L. Mann, Carlo Menon, Sébastien Miroudot, Pier Carlo Padoan, Sebastian Schich, Jean-Luc Schneider, Matthieu Segol, Stéphane Sorbe, Jan Strasky, Douglas Sutherland, Linda Tesar, Gert Wehinger, Bo Werth, William White, Eckhard Wurzel and Naomitsu Yashiro for valuable comments and suggestions. Special thanks go to Chantal Nicq $\dagger$, Alexandre Cazenave-Lacroutz and Celia Rutkoski for excellent statistical and editorial assistance. 
4. The main findings are:

- Financial value added and credit are negatively linked with GDP growth and stocks positively:

Financial sector value added and credit to the non-financial private sector (henceforth called intermediated credit) both exhibit a tight negative link with GDP growth, on average across countries at the levels observed over the past decades. By contrast, the relationship between stock market capitalisation and GDP growth is strongly positive. The associations between these three measures of finance and GDP growth hold relative to country-specific averages and trends alike.

- The empirical relationships between finance and GDP growth are very robust:

A very wide range of checks indicates robustness of the results that intermediated credit has a negative link with GDP growth and stock market size a positive one. The results continue to hold, for example, in specifications which control for financial crisis periods and eliminate business-cycle fluctuations from GDP growth. The association between financial sector value added and growth is weaker.

- More finance is associated with higher GDP growth below a threshold:

For all three indicators, expansions in financial activity from a very low level are linked with strong increases in GDP growth, while the links become negative after a threshold. On average across countries, the threshold at which more finance becomes significantly linked with slower growth is about $100 \%$ of GDP for both intermediated credit and stock market capitalisation. Most OECD countries are above this average threshold for credit but below it for stock market capitalisation. However, the framework of this study does not allow estimating country-specific thresholds which are likely to depend on financial structure, regulatory architecture and other national circumstances.

- Two different identification strategies both indicate causality in the main estimations:

A novel instrumental variables (IV) approach is employed to identify causality in the estimated links. This strategy uses indicators of financial deregulation to isolate expansions in financial activity that are not themselves driven by growth. The results for intermediated credit and stock market capitalisation continue to hold in this IV strategy. The system generalised method of moments (system GMM), which is frequently used to investigate causality in panel regressions, also indicates causality from more intermediated credit to slower growth. System GMM does not deliver conclusive results for stock market expansion, where the available data cover a much shorter period.

- More equity and less credit would support GDP growth, as would a shift to market-based debt:

The empirical results indicate that GDP growth would rise if the private sector funded itself with more equity and less debt. In addition, the estimates suggest that a shift from bank towards market-based credit would benefit GDP growth. They also point to GDP growth benefits when credit allocation shifts from household to business loans.

- Several channels account for the increasingly negative link between rising credit and growth:

Periods of more intermediated credit have been associated with $i$ ) excessive financial deregulation, ii) a more pronounced increase in credit issuance by banks than by other intermediaries, iii) larger implicit bank debt guarantees by the public authorities, iv) a lower credit quality and $v$ ) a disproportionate increase in household compared with business credit. The empirical analyses in this paper indicate that these five factors are all related with slower GDP growth. Additional transmission mechanisms might be at work. Some can be excluded, but not every single one has been, and can be, analysed empirically. 
5. The rest of the paper is organised as follows. The next section describes the data and presents the baseline results. Section 3 conducts a wide range of robustness checks. Section 4 explores whether the estimated relationships differ across countries and the extent to which they depend on the size of finance. Section 5 investigates causality. Section 6 discusses how the quality and structure of finance shape its links with growth.

\section{The overall relationship between finance and GDP growth}

6. This section first reviews what the economic literature says about the links between finance and economic growth. It then presents descriptive statistics and the econometric methodology before moving to the empirical results.

\subsection{A shifting conceptual and empirical consensus}

7. A large number of transmission channels may operate from finance to long-term GDP growth, some with the tendency to increase, others to slow down growth (for overviews, see e.g. Beck, 2012; Levine, 2005). On the one hand, greater financial development can be expected to promote long-term economic growth by allocating capital to more productive uses, smoothing the demand of individual firms and households and thereby reducing adjustment costs, and allowing more firms and households to borrow for potentially high-return investments. On the other hand, the expansion of an already large financial sector could also restrain growth by misallocating capital to projects with too low profitability, magnifying the economic costs of too-big-to-fail and other public guarantees and generating boom-and-bust cycles that reduce the long-term level of output. Investigations to date have produced evidence for both positive and negative channels: the direction of the net effect is thus an empirical question.

8. A large empirical literature has analysed the relationship between financial size and economic growth. Until the global financial crisis, the majority of studies found that deeper financial markets, often measured by intermediated credit relative to GDP, are associated with higher GDP growth. A positive link was shown to hold for unconditional (Goldsmith, 1969) and conditional cross-country correlations (King and Levine, 1993a, 1993b). Subsequently, Beck et al. (2000) and Levine et al. (2000) argued, relying on GMM estimations, that more finance causes higher GDP growth. In general, these papers cover a broad range of developed, middle-income and developing countries. Studies focusing on OECD countries found that intermediated credit is positively linked with investment but negatively with growth (Bassanini et al., 2001; Leahy et al., 2001). They also identified a positive growth effect of stock market capitalisation, a form of disintermediated finance.

9. While these papers used variations across countries and time, a separate strand of the literature exploited differences across sectors. In a seminal study, Rajan and Zingales (1998) showed that sectors more dependent on external financing usually grow faster in countries with higher financial development. Such differences-in-differences strategies have since been applied in many other contexts. For instance, sectors more dependent on external finance have been shown to grow faster in countries where securitiesmarket regulation is conducive to greater competition (de Serres et al., 2006). Such sectors are, however, also more severely affected by recessions (Braun and Larrain, 2005). The estimated parameters in these papers yield the differential impact of finance in one sector relative to another, while the absolute effect of finance on economy-wide growth remains unidentified.

10. Several recent contributions have shed doubt on the robustness of a monotonically positive link between finance and growth. Rousseau and Wachtel (2011) find that the positive correlation of financial size with economic growth disappears when concentrating on the period since 1990. Other papers argue that the relationship is hump-shaped, with financial deepening being associated with higher GDP growth at low levels of financial development and slower GDP growth above a certain threshold (Arcand et al., 
2012; Beck et al., 2014; Cecchetti and Kharroubi, 2012; Law and Singh, 2014). This threshold for intermediated credit is estimated to be about $90 \%$ of GDP. Re-estimating the regressions of the Rajan and Zingales (1998) approach in the sample of OECD countries, Pagano and Pica (2012) find that higher financial development has no particularly positive impact on the growth of sectors dependent on external finance. In the realm of disintermediated finance, Tridico (2013) presents evidence that in Europe larger stock markets were associated with a worse growth performance during the global financial crisis.

\subsection{A new look at the data}

11. This subsection introduces the empirical approach that the next subsection uses to re-examine the link of finance with economic growth in OECD and G20 countries. It starts by looking at how the value added of finance, intermediated credit and stock market capitalisation, each divided by GDP, correlate with real GDP per capita growth. The value added of finance and intermediated credit by definition include output by deposit money banks, insurance companies and other financial institutions. Appendix 1 describes the data sources for this paper. The variables are demeaned by their respective average for each country to remove the bias which might arise from persistent differences between countries.

12. This first glance at the data reveals that the association between financial size and GDP growth varies across different forms of finance. The relationship is statistically significant at the $0.1 \%$ level, with a correlation coefficient of $-18 \%$, for the value added of finance (Figure 1). The correlation is stronger, with a coefficient of $-33 \%$, in the case of intermediated credit (Figure 2) and also statistically significant at the $0.1 \%$ level. These correlations underline that the value added of finance and intermediated credit expanded and GDP growth slowed down in tandem over the past half-century. The econometric analysis that follows investigates whether these negative associations remain after accounting for time trends and other factors that could confound the relationships. Stock market capitalisation exhibits the opposite link with GDP growth, in the same statistically significant fashion, so that GDP growth rises at times when stock markets expand (Figure 3 ). The correlation coefficient is $21 \%$. 
ECO/WKP(2015)41

Figure 1. The bivariate relationship between the value added of finance and GDP growth per capita

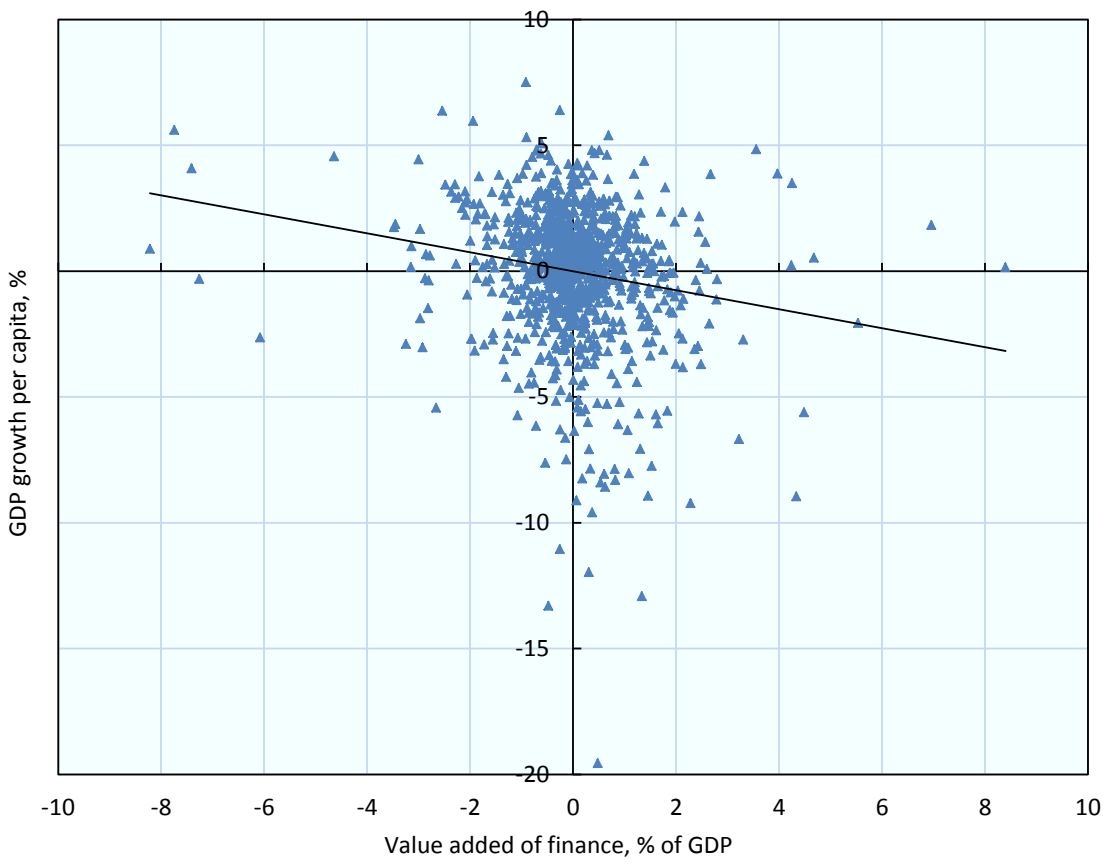

Note: The sample covers 32 OECD countries between 1970 and 2011. The line indicates the fitted values of an OLS regression through the data points. The two variables are demeaned using the respective country means to average out differences between countries that are persistent over time.

Source: OECD Structural Analysis database; World Bank World Development Indicators database; OECD Secretariat calculations.

Figure 2. The bivariate relationship between intermediated credit and GDP growth per capita

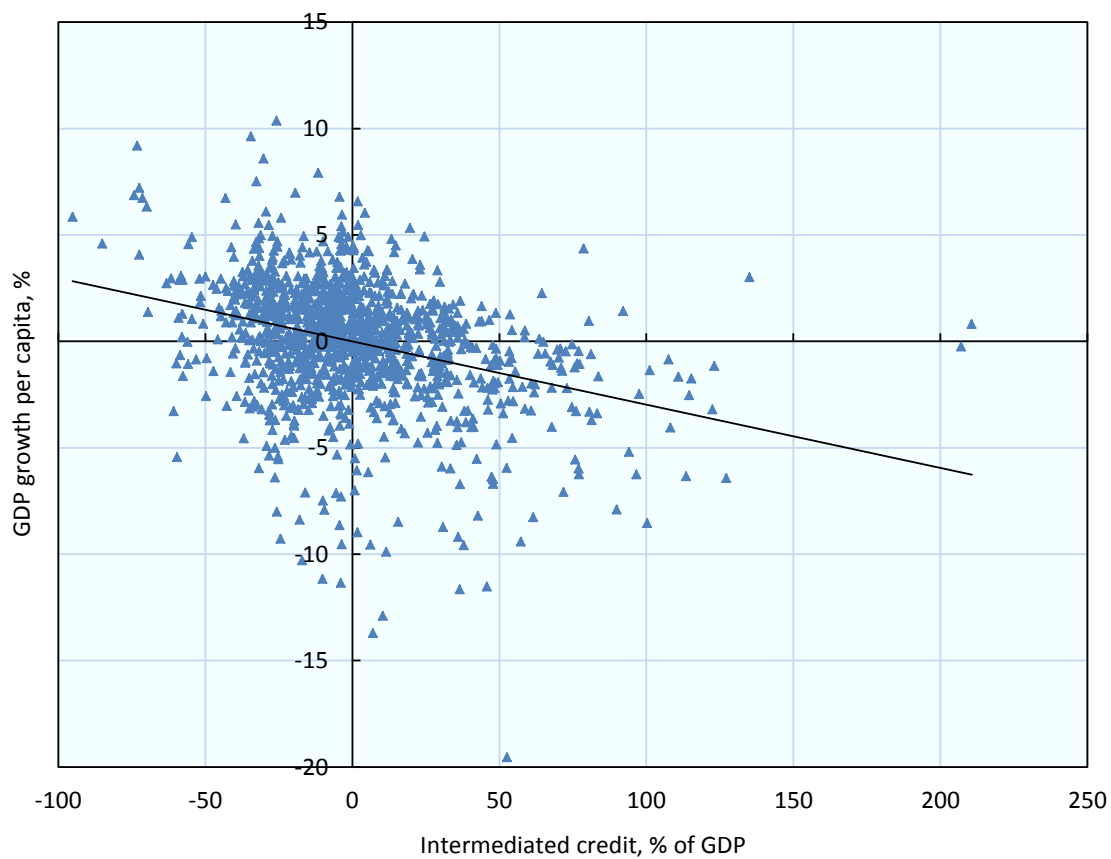

Note: The sample covers all 34 OECD countries between 1961 and 2011. The line indicates the fitted values of an OLS regression through the data points. The two variables are demeaned using the respective country means to average out differences between countries that are persistent over time.

Source: World Bank Global Financial Development database; Bank for International Settlements credit series; Statistics Canada; World Bank World Development Indicators database, OECD Secretariat calculations. 
Figure 3. The bivariate relationship between stock market capitalisation and GDP growth per capita

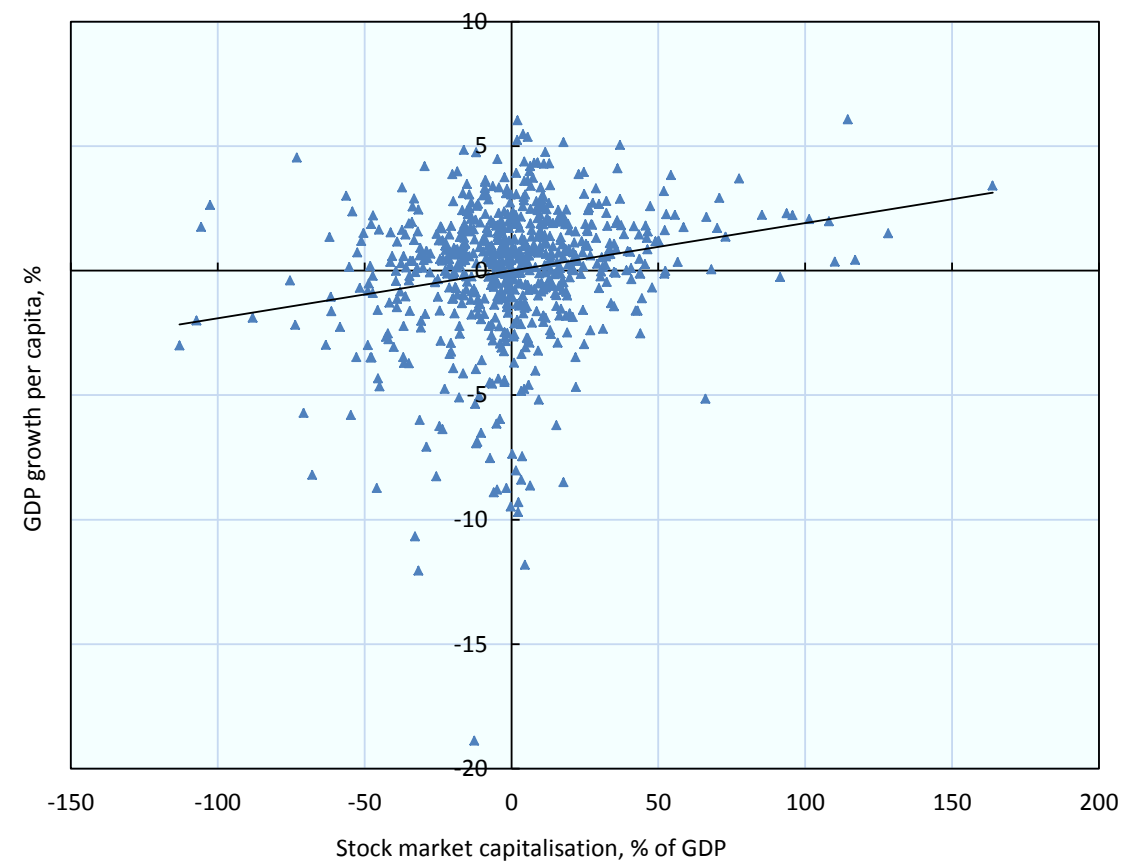

Note: The sample covers all 34 OECD countries between 1989 and 2011. The line indicates the fitted values of an OLS regression through the data points. The two variables are demeaned using the respective country means to average out differences between countries that are persistent over time.

Source: World Bank Global Financial Development database; World Bank World Development Indicators database; OECD Secretariat calculations.

13. The baseline specification to estimate the relationship between GDP growth and finance is:

$$
\text { Growth }_{c t}=\beta \text { Fin }_{c t}+x_{c t} \gamma+\rho_{c}+\tau_{t}+\varphi_{c} t+\varepsilon_{c t} .
$$

The dependent variable Growth $_{c t}$ is the percentage point growth of real GDP per capita. The parameter of interest is the coefficient $\beta$ which is the conditional correlation of GDP growth with the chosen measure of finance, Fin $_{c t}$ : the value added of finance, intermediated credit or stock market capitalisation. $c$ and $t$ are indices for country and year. Standard errors are clustered at the country-level to account for heteroscedasticity and autocorrelation in the error term for observations from the same country (Angrist and Pischke, 2009; Liang and Zeger, 1986). The idiosyncratic disturbances are denoted by $\varepsilon_{c t}$.

14. The baseline specification controls for other growth determinants, $x_{c t}$, that are commonly used in the literature and that naturally arise in a human-capital-augmented Solow model with a standard CobbDouglas production function (Arnold et al., 2011; Caselli et al., 1996; Mankiw et al., 1992). These are: gross fixed capital formation (or the investment rate), the stock of human capital proxied by average years of schooling of the adult population and the growth rate of the working age population. Country fixed effects $\rho_{c}$ account for time-invariant country-specific characteristics influencing GDP growth, and $\tau_{t}$ are year fixed effects which capture OECD- and G20-wide shocks to GDP growth. Results are also presented without year fixed effects.

15. The set of country-specific coefficients $\varphi_{c}$ on the linear time trend $t$ accounts for the long-term downward trend of GDP growth rates in many OECD countries, thereby removing its potentially spurious correlation with the concomitant rise of financial indicators. To check robustness, the link between each measure of finance and GDP growth is estimated relative to a country's average level of finance and to its trend. The specification without trends includes the natural logarithm of lagged real GDP to account for 
convergence and reduce the potentially spurious correlation between the trend rise of finance and the trend slowdown of GDP growth in many countries.

16. The estimation strategy comes with two caveats. The first is on the interpretation of the parameter $\beta$. As was mentioned, many countries experienced a long-term rise of finance over the sample period. The effect of this rise is absorbed in the country-specific linear time trends and also the year fixed effects which account for all year-to-year changes that are common across countries. As a result, the inclusion of linear time trends and year fixed effects means that the correlation between finance and GDP growth is identified in relative, not absolute terms. The parameter $\beta$ captures the relationship between changes in the size of finance and changes in GDP growth in one country relative to others. The same applies to all differencesin-differences specifications which typically do not estimate the average influence of the variable of interest.

17. The second caveat is that this set of regressions is not conclusive about the direction of causation. The inclusion of linear time trends and year fixed effects reduces one source of potential endogeneity: the long-term slowdown in GDP growth and rise of finance in many countries. Furthermore, country fixed effects remove omitted variables bias related with country specificities that do not vary over time. However, this does not rule out reverse causation. To illustrate with one example: a negative association between GDP growth and intermediated credit could be interpreted as too much private sector debt holding back GDP growth. But an alternative interpretation could be that in periods of slow GDP growth the financial sector performs its role as credit provider to the economy, providing loans to households and companies precisely when it is most needed. These issues of causality are tackled in Section 5 below.

\subsection{Empirical results}

18. The value added of finance is negatively related with GDP growth (Table 1). This is independent of whether the relationship is estimated relative to a country's average level of financial sector value added or to its trend. The coefficient on value added is statistically significant when only country fixed effects are included (Column 1). It becomes insignificant with the standard control variables (Column 2). However, introducing year fixed effects increases the absolute size of the coefficient, and it turns again statistically significant (Column 3). The addition of country-specific linear time trends yields also a significant estimate (Column 4). This specification is taken to be the baseline, as it most strongly accounts for the concern that the negative coefficient could result from a spurious correlation between the trend rise of finance and the trend slowdown of GDP growth. According to the baseline results, a one percentage point increase in the share of finance in GDP is associated with 0.3 percentage points lower GDP growth. ${ }^{2}$

19. The same exercise is conducted using intermediated credit, which shows that more intermediated credit is also related with slower GDP growth (Table 2). Again, this negative relationship does not depend on whether it is estimated relative to a country's average level of intermediated credit or to its trend. The coefficient is statistically significant at a confidence level of $95 \%$ or above in all specifications: with country fixed effects (Column 1), after including the standard control variables (Column 2), with year fixed effects (Column 3) and with country-specific linear time trends in the sample of OECD countries (Column 4). A rise of intermediated credit by $10 \%$ of GDP translates into a GDP growth rate that is 0.3 percentage points less than otherwise. ${ }^{3}$ The estimate remains similar when the sample is expanded to the eight non-OECD G20 countries (Column 5). Statistical gaps preclude testing the role of financial sector value added in the extended dataset covering OECD and G20 countries.

2. The standard deviation of financial sector value added is $3 / 4$ per cent of GDP after controlling for exogenous covariates, country fixed effects, year fixed effects and country-specific linear time trends.

3. The standard deviation of intermediated credit is $15 \%$ of GDP after controlling for exogenous covariates, country fixed effects, year fixed effects and country-specific linear time trends. 
20. Greater stock market capitalisation exhibits a highly significant link with stronger GDP growth (Table 3), in stark contrast to the value added of finance and intermediated credit. This result holds relative to a country's average level of stock market capitalisation with and without controlling for the standard growth determinants and year fixed effects (Columns 1-3). It likewise holds relative to a country's trend in the OECD and OECD and G20 country samples (Columns 4-5). According to the baseline estimate, an increase in stock market capitalisation by $10 \%$ of GDP is, on average across countries, associated with a rise of GDP growth by 0.2 percentage points. ${ }^{4}$ The estimates apply at the average levels observed over past decades. They may be different at different stages of financial development, which is an issue Section 4 investigates in detail. The coefficients on the other explanatory variables exhibit broadly the expected sign: for instance, investment and sometimes education have significant positive links with GDP growth.

4. The standard deviation of stock market capitalisation is $18 \%$ of GDP after controlling for exogenous covariates, country fixed effects, year fixed effects and country-specific linear time trends. 
Table 1. The relationship between the value added of finance and GDP growth per capita

\begin{tabular}{|c|c|c|c|c|c|c|}
\hline \multirow[t]{2}{*}{ Dependent variable: } & \multicolumn{6}{|c|}{ GDP growth per capita } \\
\hline & (1) & (2) & (3) & (4) & (5) & (6) \\
\hline Value added of finance & $\begin{array}{c}-0.377^{* * *} \\
(0.075)\end{array}$ & $\begin{array}{l}-0.060 \\
(0.092)\end{array}$ & $\begin{array}{l}-0.171^{* *} \\
(0.066)\end{array}$ & $\begin{array}{l}-0.261^{* *} \\
(0.122)\end{array}$ & $\begin{array}{c}-0.281^{* *} \\
(0.123)\end{array}$ & $\begin{array}{c}-0.242^{\star *} \\
(0.107)\end{array}$ \\
\hline Investment rate & - & $\begin{array}{c}0.207^{* \star \star} \\
(0.049)\end{array}$ & $\begin{array}{c}0.195^{\star \star * *} \\
(0.050)\end{array}$ & $\begin{array}{c}0.188^{* * *} \\
(0.046)\end{array}$ & $\begin{array}{c}0.161^{* \star *} \\
(0.044)\end{array}$ & $\begin{array}{c}0.179^{* * *} \\
(0.050)\end{array}$ \\
\hline School years & - & $\begin{array}{c}0.538 \\
(0.337)\end{array}$ & $\begin{array}{l}-0.179 \\
(0.255)\end{array}$ & $\begin{array}{l}1.465^{*} \\
(0.799)\end{array}$ & $\begin{array}{l}1.681^{* *} \\
(0.810)\end{array}$ & $\begin{array}{l}1.370^{*} \\
(0.725)\end{array}$ \\
\hline Population growth & - & $\begin{array}{c}-0.700^{* \star *} \\
(0.207)\end{array}$ & $\begin{array}{c}-0.472^{\star *} \\
(0.178)\end{array}$ & $\begin{array}{l}-0.198 \\
(0.220)\end{array}$ & $\begin{array}{l}-0.474^{*} \\
(0.244)\end{array}$ & $\begin{array}{l}-0.223 \\
(0.208)\end{array}$ \\
\hline In(Lagged GDP per capita) & - & $\begin{array}{c}-4.474^{\star \star \star} \\
(1.234)\end{array}$ & $\begin{array}{c}-3.645^{\star \star \star} \\
(1.227)\end{array}$ & - & - & - \\
\hline Banking crisis dummy & - & - & - & - & - & $\begin{array}{c}-1.205^{\star *} \\
(0.458)\end{array}$ \\
\hline Year fixed effects & No & No & Yes & Yes & Yes & Yes \\
\hline Linear country trends & No & No & No & Yes & Yes & Yes \\
\hline R-squared & 0.162 & 0.251 & 0.555 & 0.592 & 0.510 & 0.601 \\
\hline Sample period & $1970-2011$ & $1970-2011$ & $1970-2011$ & $1970-2011$ & $1970-2006$ & $1970-2011$ \\
\hline Observations & 948 & 948 & 948 & 948 & 798 & 948 \\
\hline
\end{tabular}

Note: All regressions are OLS and contain country fixed effects. Standard errors, which are shown in brackets, are clustered at the country-level. ${ }^{* * *}$ indicates significance at the $1 \%$ level, ${ }^{* *}$ at the $5 \%$ level and ${ }^{*}$ at the $10 \%$ level. Value added of finance is financial and insurance activities divided by GDP, investment rate is gross fixed capital formation divided by GDP, school years is average years of schooling in the population aged 25 and over, and population growth is the growth rate of the population aged 15-64. The sample covers 32 OECD countries.

Source: OECD Secretariat calculations using OECD Structural Analysis database; World Bank World Development Indicators database; OECD Economic Outlook database; R. J. Barro and J. W. Lee (2013), "A New Data Set of Educational Attainment in the World, 1950-2010", Journal of Development Economics, 104, pp. 184-198; L. Laeven and F. Valencia (2013), "Systemic Banking Crises Database", IMF Economic Review, 61(2), pp. 225-270. 


\begin{tabular}{|c|c|c|c|c|c|c|c|}
\hline \multirow{2}{*}{$\begin{array}{l}\text { Dependent variable: } \\
\text { Sample: }\end{array}$} & \multicolumn{7}{|c|}{ GDP growth per capita } \\
\hline & $\begin{array}{c}\text { OECD } \\
(1) \\
\end{array}$ & $\begin{array}{c}\text { OECD } \\
(2) \\
\end{array}$ & $\begin{array}{c}\text { OECD } \\
(3) \\
\end{array}$ & $\begin{array}{c}\text { OECD } \\
(4)\end{array}$ & $\begin{array}{c}\text { OECD \& G20 } \\
(5) \\
\end{array}$ & $\begin{array}{c}\text { OECD } \\
(6)\end{array}$ & $\begin{array}{c}\text { OECD } \\
(7) \\
\end{array}$ \\
\hline Intermediated credit & $\begin{array}{c}-0.031^{* * *} \\
(0.005)\end{array}$ & $\begin{array}{c}-0.016^{\star *} \\
(0.006)\end{array}$ & $\begin{array}{c}-0.021^{* * *} \\
(0.006)\end{array}$ & $\begin{array}{c}-0.029^{* * *} \\
(0.008)\end{array}$ & $\begin{array}{c}-0.034^{* * *} \\
(0.011)\end{array}$ & $\begin{array}{c}-0.031^{* * *} \\
(0.010)\end{array}$ & $\begin{array}{c}-0.019^{\star *} \\
(0.009)\end{array}$ \\
\hline Investment rate & - & $\begin{array}{c}0.191^{\star \star *} \\
(0.039)\end{array}$ & $\begin{array}{c}0.211^{* * *} \\
(0.040)\end{array}$ & $\begin{array}{c}0.245^{\star \star *} \\
(0.043)\end{array}$ & $\begin{array}{c}0.144 \\
(0.095)\end{array}$ & $\begin{array}{c}0.224^{\star * *} \\
(0.041)\end{array}$ & $\begin{array}{c}0.254^{* * *} \\
(0.051)\end{array}$ \\
\hline School years & - & $\begin{array}{c}0.375 \\
(0.291)\end{array}$ & $\begin{array}{l}-0.482^{*} \\
(0.246)\end{array}$ & $\begin{array}{l}-0.008 \\
(0.302)\end{array}$ & $\begin{array}{c}0.653 \\
(0.448)\end{array}$ & $\begin{array}{c}0.179 \\
(0.322)\end{array}$ & $\begin{array}{c}0.222 \\
(0.491)\end{array}$ \\
\hline Population growth & - & $\begin{array}{l}-0.476 \\
(0.319)\end{array}$ & $\begin{array}{l}-0.356 \\
(0.263)\end{array}$ & $\begin{array}{c}-0.674^{* *} \\
(0.311)\end{array}$ & $\begin{array}{c}-0.990^{* * *} \\
(0.267)\end{array}$ & $\begin{array}{c}-0.696^{* *} \\
(0.330)\end{array}$ & $\begin{array}{l}-0.710^{*} \\
(0.369)\end{array}$ \\
\hline In(Lagged GDP per capita) & - & $\begin{array}{c}-2.661^{\star *} \\
(1.090)\end{array}$ & $\begin{array}{c}-4.114^{\star * *} \\
(1.213)\end{array}$ & - & - & - & - \\
\hline Banking crisis dummy & - & - & - & - & - & - & $\begin{array}{c}-1.183^{\star *} \\
(0.466)\end{array}$ \\
\hline Year fixed effects & No & No & Yes & Yes & Yes & Yes & Yes \\
\hline Linear country trends & No & No & No & Yes & Yes & Yes & Yes \\
\hline R-squared & 0.183 & 0.242 & 0.483 & 0.508 & 0.429 & 0.438 & 0.520 \\
\hline Sample period & $1961-2011$ & $1961-2011$ & $1961-2011$ & $1961-2011$ & $1961-2011$ & $1961-2006$ & $1970-2011$ \\
\hline Observations & 1303 & 1260 & 1260 & 1260 & 1553 & 1111 & 1115 \\
\hline
\end{tabular}

Note: All regressions are OLS and contain country fixed effects. Standard errors, which are shown in brackets, are clustered at the country-level. ${ }^{* * *}$ indicates significance at the $1 \%$ level, ${ }^{* *}$ at the $5 \%$ level and * at the $10 \%$ level. Intermediated credit is credit to the non-financial private sector by financial institutions divided by GDP, investment rate is gross fixed capital formation divided by GDP, school years is average years of schooling in the population aged 25 and over, and population growth is the growth rate of the population aged 15-64. The sample covers 33 OECD countries, apart from Column 5 which also includes the 8 non-OECD G20 countries.

Source: OECD Secretariat calculations using World Bank Global Financial Development database; Bank for International Settlements credit series; Statistics Canada; World Bank World Development Indicators database; OECD Economic Outlook database; R. J. Barro and J. W. Lee (2013), "A New Data Set of Educational Attainment in the World, 1950-2010", Journal of Development Economics, 104, pp. 184-198; L. Laeven and F. Valencia (2013), "Systemic Banking Crises Database", IMF Economic Review, 61(2), pp. 225-270. 
Table 3. The relationship between stock market capitalisation and GDP growth per capita

\begin{tabular}{|c|c|c|c|c|c|c|c|}
\hline \multirow{2}{*}{$\begin{array}{l}\text { Dependent variable: } \\
\text { Sample: }\end{array}$} & \multicolumn{7}{|c|}{ GDP growth per capita } \\
\hline & $\begin{array}{c}\text { OECD } \\
(1) \\
\end{array}$ & $\begin{array}{l}\text { OECD } \\
(2) \\
\end{array}$ & $\begin{array}{l}\text { OECD } \\
(3) \\
\end{array}$ & $\begin{array}{l}\text { OECD } \\
(4) \\
\end{array}$ & $\begin{array}{c}\text { OECD \& G20 } \\
(5)\end{array}$ & $\begin{array}{l}\text { OECD } \\
(6) \\
\end{array}$ & $\begin{array}{c}\text { OECD } \\
(7)\end{array}$ \\
\hline Stock market capitalisation & $\begin{array}{c}0.019^{* * *} \\
(0.004)\end{array}$ & $\begin{array}{c}0.034^{* * *} \\
(0.005)\end{array}$ & $\begin{array}{l}0.017^{\star * *} \\
(0.004)\end{array}$ & $\begin{array}{c}0.018^{* * *} \\
(0.005)\end{array}$ & $\begin{array}{c}0.015^{\star * *} \\
(0.005)\end{array}$ & $\begin{array}{c}0.021^{* * *} \\
(0.007)\end{array}$ & $\begin{array}{c}0.015^{\star * *} \\
(0.004)\end{array}$ \\
\hline Investment rate & - & $\begin{array}{c}0.275^{\star \star \star} \\
(0.060)\end{array}$ & $\begin{array}{c}0.232^{* \star *} \\
(0.063)\end{array}$ & $\begin{array}{c}0.277^{\star \star *} \\
(0.074)\end{array}$ & $\begin{array}{c}0.291^{* \star *} \\
(0.077)\end{array}$ & $\begin{array}{c}0.216^{\star \star *} \\
(0.076)\end{array}$ & $\begin{array}{c}0.245^{\star \star \star} \\
(0.081)\end{array}$ \\
\hline School years & - & $\begin{array}{c}0.287 \\
(0.400)\end{array}$ & $\begin{array}{l}-0.209 \\
(0.359)\end{array}$ & $\begin{array}{c}0.874 \\
(1.154)\end{array}$ & $\begin{array}{c}1.658 \\
(1.522)\end{array}$ & $\begin{array}{c}0.215 \\
(1.233)\end{array}$ & $\begin{array}{c}0.588 \\
(1.151)\end{array}$ \\
\hline Population growth & - & $\begin{array}{c}-0.982^{* * *} \\
(0.265)\end{array}$ & $\begin{array}{c}-0.623^{\star *} \\
(0.283)\end{array}$ & $\begin{array}{l}-0.476 \\
(0.393)\end{array}$ & $\begin{array}{c}-0.610^{* *} \\
(0.248)\end{array}$ & $\begin{array}{c}-0.494 \\
(0.471)\end{array}$ & $\begin{array}{l}-0.467 \\
(0.384)\end{array}$ \\
\hline In(Lagged GDP per capita) & - & $\begin{array}{c}-8.296^{\star * *} \\
(1.435)\end{array}$ & $\begin{array}{c}-7.107^{\star * *} \\
(2.024)\end{array}$ & - & - & - & - \\
\hline Banking crisis dummy & - & - & - & - & - & - & $\begin{array}{c}-1.207^{\star *} \\
(0.511)\end{array}$ \\
\hline Year fixed effects & No & No & Yes & Yes & Yes & Yes & Yes \\
\hline Linear country trends & No & No & No & Yes & Yes & Yes & Yes \\
\hline R-squared & 0.162 & 0.346 & 0.572 & 0.596 & 0.562 & 0.499 & 0.605 \\
\hline Sample period & $1989-2011$ & $1989-2011$ & $1989-2011$ & $1989-2011$ & $1989-2011$ & $1989-2006$ & $1989-2011$ \\
\hline Observations & 705 & 702 & 702 & 702 & 871 & 536 & 702 \\
\hline
\end{tabular}

Note: All regressions are OLS and contain country fixed effects. Standard errors, which are shown in brackets, are clustered at the country-level. ${ }^{\star \star \star}$ indicates significance at the $1 \%$ Note: All regressions are OLS and contain country fixed effects. Standard errors, which are shown in brackets, are clustered at the country-level. ${ }^{* *}$ indicates significance at the $1 \%$
level, ${ }^{* *}$ at the $5 \%$ level and ${ }^{*}$ at the $10 \%$ level. Stock market capitalisation is the value of all shares listed in a stock market divided by GDP, investment rate is gross fixed capital formation divided by GDP, school years is average years of schooling in the population aged 25 and over, and population growth is the growth rate of the population aged $15-64$. The formation divided by GDP, school years is average years of schooling in the population aged 25 and over, and
sample covers all OECD countries, apart from Column 5 which also includes the 8 non-OECD G20 countries.

Source: OECD Secretariat calculations using World Bank Global Financial Development database; World Bank World Development Indicators database; OECD Economic Outlook database; R. J. Barro and J. W. Lee (2013), "A New Data Set of Educational Attainment in the World, 1950-2010", Journal of Development Economics, 104, pp. 184-198; L. Laeven and F. Valencia (2013), "Systemic Banking Crises Database", IMF Economic Review, 61(2), pp. 225-270. 


\section{Robustness checks}

21. This section examines the role of financial crisis periods, additional control variables, businesscycle fluctuations, investment, innovation, the labour share and outlier observations for the finance and growth relationship.

\section{Financial crisis periods}

22. Past research indicates that banking crises can permanently harm economic performance (Cerra and Saxena, 2008; Furceri and Mourougane, 2012; Ollivaud and Turner, 2014) and that debt overshoots tend to destabilise the economy (Schularick and Taylor, 2012; Sutherland et al., 2012). The estimates in this paper suggest, however, that the direct GDP impacts of banking crises are not the primary driver of the negative association between finance and growth.

23. For each measure of finance, two tests are conducted to study the role of financial crisis periods (Tables 1-3): the sample period is restricted up to 2006, before the global financial crisis, and financial crisis periods are controlled for with the indicator of Laeven and Valencia (2013). The estimates from the baseline specification in Column 4 remain statistically significant when the sample period is restricted up to 2006 (Column 5 in Table 1 and Column 6 in Tables 2-3) and also when the financial crisis dummy is introduced (Column 6 in Table 1 and Column 7 in Tables 2-3). The size of the coefficients is generally not very sensitive to these checks, perhaps with the exception of intermediated credit where the coefficient falls by about one third when financial crises are controlled for. Financial crises themselves are negatively related with GDP growth.

\section{Additional control variables}

24. Omitted variables might in theory bias the estimates, but in practice the country fixed effects, year fixed effects and country-specific linear time trends account for a large part of the variation in the data. To further check robustness in this dimension, regressions have been run that include private consumption, government consumption and trade openness (the sum of imports and exports), expressed in per cent of GDP, as covariates. The effect on the size and statistical significance of the finance coefficients is small; all three are significant with $99 \%$ confidence (Table 4 ).

\section{Business-cycle fluctuations}

25. The relationships between finance and GDP growth remain similar when using alternative measures for GDP to isolate the structural growth path. Therefore, the associations between finance and growth estimated in Tables 1-3 are not primarily related to business-cycle fluctuations. In particular, the positive link between stock markets and growth goes beyond the demand effects generated by stock-price movements.

- In a first robustness check, potential GDP replaces actual GDP (Table 5). Regressions are run relative to levels (Columns 1, 3 and 5) and to trends (Columns 2, 4 and 6). The coefficients are smaller in absolute value than when using actual GDP, but remain statistically significant apart from the value added of finance.

- In a second robustness check, five-year averages are calculated for all variables (Table 6), as in many papers studying the finance-growth link, including Arcand et al. (2012), Beck et al. (2000), Law and Singh (2014) and Rousseau and Wachtel (2011). Substituting five-year averages for annual data seriously reduces the number of observations. The regressions are therefore run without linear time trends (Columns 1, 3 and 5), given the much smaller number of time periods. The coefficients are very close to those using yearly data and are of similar statistical significance, again apart from the value added of finance. 
ECO/WKP(2015)41

Table 4. The role of consumption and trade for the finance and growth relationship

\begin{tabular}{|c|c|c|c|}
\hline \multirow{2}{*}{$\begin{array}{l}\text { Dependent variable: } \\
\text { Measure of finance: }\end{array}$} & \multicolumn{3}{|c|}{ GDP growth per capita } \\
\hline & $\begin{array}{c}\text { Value added of } \\
\text { finance } \\
(1) \\
\end{array}$ & $\begin{array}{l}\text { Intermediated credit } \\
\text { (2) }\end{array}$ & $\begin{array}{c}\text { Stock market } \\
\text { capitalisation } \\
(3) \\
\end{array}$ \\
\hline Measure of finance & $\begin{array}{l}-0.283^{\star * *} \\
(0.102)\end{array}$ & $\begin{array}{l}-0.025^{\star \star \star} \\
(0.009)\end{array}$ & $\begin{array}{l}0.013^{\star \star \star} \\
(0.004)\end{array}$ \\
\hline Investment rate & $\begin{array}{l}0.188^{* * *} \\
(0.060)\end{array}$ & $\begin{array}{l}0.198^{* * *} \\
(0.064)\end{array}$ & $\begin{array}{l}0.306^{\star * *} \\
(0.058)\end{array}$ \\
\hline School years & $\begin{array}{c}0.693 \\
(0.694)\end{array}$ & $\begin{array}{l}-0.123 \\
(0.318)\end{array}$ & $\begin{array}{c}0.561 \\
(0.921)\end{array}$ \\
\hline Population growth & $\begin{array}{l}-0.263 \\
(0.246)\end{array}$ & $\begin{array}{l}-0.861^{* *} \\
(0.328)\end{array}$ & $\begin{array}{l}-0.535 \\
(0.352)\end{array}$ \\
\hline Private consumption & $\begin{array}{l}-0.102^{*} \\
(0.059)\end{array}$ & $\begin{array}{l}-0.033 \\
(0.063)\end{array}$ & $\begin{array}{l}-0.028 \\
(0.087)\end{array}$ \\
\hline Government consumption & $\begin{array}{l}-0.259^{\star *} \\
(0.117)\end{array}$ & $\begin{array}{l}-0.213^{* *} \\
(0.100)\end{array}$ & $\begin{array}{l}-0.381^{* *} \\
(0.172)\end{array}$ \\
\hline Trade openness & $\begin{array}{c}0.081^{* * *} \\
(0.020)\end{array}$ & $\begin{array}{c}0.021 \\
(0.024)\end{array}$ & $\begin{array}{c}0.099^{* * *} \\
(0.026)\end{array}$ \\
\hline Year fixed effects & Yes & Yes & Yes \\
\hline Linear country trends & Yes & Yes & Yes \\
\hline R-squared & 0.631 & 0.530 & 0.658 \\
\hline Sample period & $1970-2011$ & $1961-2011$ & $1989-2011$ \\
\hline Observations & 948 & 1218 & 688 \\
\hline
\end{tabular}

Note: All regressions are OLS and contain country fixed effects. Standard errors, which are shown in brackets, are clustered at the country-level. ${ }^{* \star *}$ indicates significance at the $1 \%$ level, ${ }^{* *}$ at the $5 \%$ level and ${ }^{*}$ at the $10 \%$ level. Value added of finance is financial and insurance activities divided by GDP, intermediated credit is credit to the non-financial private sector by financial institutions divided by GDP, and stock market capitalisation is the value of all shares listed in a stock market divided by GDP. Investment rate is gross fixed capital formation divided by GDP, school years is average years of schooling in the population aged 25 and over, and population growth is the growth rate of the population aged 15-64. Private consumption, government consumption and trade openness (the sum of imports and exports) are expressed as shares of GDP. The sample covers 32-34 OECD countries.

Source: OECD Secretariat calculations using OECD Structural Analysis database; World Bank Global Financial Development database; Bank for International Settlements credit series; Statistics Canada; OECD Economic Outlook database; R. J. Barro and J. W. Lee (2013), "A New Data Set of Educational Attainment in the World, 1950-2010", Journal of Development Economics, 104, pp. 184-198; World Bank World Development Indicators database. 
Table 5. The relationship between finance and growth of potential GDP per capita

\begin{tabular}{|c|c|c|c|c|c|c|}
\hline \multirow{3}{*}{$\begin{array}{l}\text { Dependent variable: } \\
\text { Measure of finance: }\end{array}$} & \multicolumn{6}{|c|}{ Growth of potential GDP per capita } \\
\hline & \multicolumn{2}{|c|}{ Value added of finance } & \multicolumn{2}{|c|}{ Intermediated credit } & \multicolumn{2}{|c|}{ Stock market capitalisation } \\
\hline & $(1)$ & $(2)$ & (3) & (4) & $(5)$ & (6) \\
\hline Measure of finance & $\begin{array}{l}-0.060 \\
(0.053)\end{array}$ & $\begin{array}{l}-0.072 \\
(0.049)\end{array}$ & $\begin{array}{l}-0.010^{*} \\
(0.006)\end{array}$ & $\begin{array}{l}-0.019^{\star \star} \\
(0.007)\end{array}$ & $\begin{array}{l}0.008^{\star *} \\
(0.003)\end{array}$ & $\begin{array}{l}0.008^{\star \star} \\
(0.003)\end{array}$ \\
\hline Investment rate & $\begin{array}{l}0.094^{* *} \\
(0.039)\end{array}$ & $\begin{array}{l}0.115^{\star \star \star} \\
(0.032)\end{array}$ & $\begin{array}{l}0.121^{\star \star *} \\
(0.034)\end{array}$ & $\begin{array}{l}0.107^{\star \star *} \\
(0.035)\end{array}$ & $\begin{array}{l}0.117^{* *} \\
(0.053)\end{array}$ & $\begin{array}{c}0.132^{* \star *} \\
(0.036)\end{array}$ \\
\hline School years & $\begin{array}{l}-0.115 \\
(0.164)\end{array}$ & $\begin{array}{c}0.745 \\
(0.475)\end{array}$ & $\begin{array}{l}-0.249 \\
(0.176)\end{array}$ & $\begin{array}{c}0.448 \\
(0.351)\end{array}$ & $\begin{array}{l}-0.088 \\
(0.256)\end{array}$ & $\begin{array}{c}0.024 \\
(0.434)\end{array}$ \\
\hline Population growth & $\begin{array}{c}0.108 \\
(0.256)\end{array}$ & $\begin{array}{c}0.023 \\
(0.289)\end{array}$ & $\begin{array}{c}0.175 \\
(0.264)\end{array}$ & $\begin{array}{c}0.095 \\
(0.301)\end{array}$ & $\begin{array}{l}-0.402 \\
(0.266)\end{array}$ & $\begin{array}{l}-0.395 \\
(0.253)\end{array}$ \\
\hline $\begin{array}{l}\text { In(Lagged potential GDP } \\
\text { per capita) }\end{array}$ & $\begin{array}{l}-2.311^{* * *} \\
(0.817)\end{array}$ & - & $\begin{array}{l}-1.149 \\
(0.864)\end{array}$ & - & $\begin{array}{l}-3.858^{*} \\
(2.249)\end{array}$ & - \\
\hline Year fixed effects & Yes & Yes & Yes & Yes & Yes & Yes \\
\hline Linear country trends & No & Yes & No & Yes & No & Yes \\
\hline R-squared & 0.716 & 0.829 & 0.658 & 0.790 & 0.706 & 0.889 \\
\hline Sample period & $1970-2008$ & $1970-2008$ & $1967-2008$ & $1967-2008$ & $1989-2008$ & $1989-2008$ \\
\hline Observations & 784 & 784 & 874 & 874 & 553 & 553 \\
\hline
\end{tabular}

Note: All regressions are OLS and contain country fixed effects. Standard errors, which are shown in brackets, are clustered at the country-level. *** indicates significance at the $1 \%$ level, ${ }^{* *}$ at the $5 \%$ level and ${ }^{*}$ at the $10 \%$ level. Value added of finance is financial and insurance activities divided by GDP, intermediated credit is credit to the non-financial private sector by financial institutions divided by GDP, and stock market capitalisation is the value of all shares listed in a stock market divided by GDP. Investment rate is gross fixed capital formation divided by GDP, school years is average years of schooling in the population aged 25 and over, and population growth is the growth rate of the population aged 15-64. The sample covers 29-30 OECD countries.

Source: OECD Secretariat calculations using OECD Structural Analysis database; World Bank Global Financial Development database; Bank for International Settlements credit series; Statistics Canada; OECD Economic Outlook database; R. J. Barro and J. W. Lee (2013), "A New Data Set of Educational Attainment in the World, 1950-2010", Journal of Development Economics, 104, pp. 184-198; World Bank World Development Indicators database. 
Table 6. The relationship between finance and GDP growth per capita using five-year averages

\begin{tabular}{|c|c|c|c|c|c|c|}
\hline \multirow{3}{*}{$\begin{array}{l}\text { Dependent variable: } \\
\text { Measure of finance: } \\
\text { Estimator: }\end{array}$} & \multicolumn{6}{|c|}{ GDP growth per capita } \\
\hline & \multicolumn{2}{|c|}{ Value added of finance } & \multicolumn{2}{|c|}{ Intermediated credit } & \multicolumn{2}{|c|}{ Stock market capitalisation } \\
\hline & $\begin{array}{c}\text { OLS } \\
(1)\end{array}$ & $\begin{array}{c}\text { GMM } \\
(2)\end{array}$ & $\begin{array}{c}\text { OLS } \\
(3)\end{array}$ & $\begin{array}{c}\text { GMM } \\
(4)\end{array}$ & $\begin{array}{c}\text { OLS } \\
(5)\end{array}$ & $\begin{array}{c}\text { GMM } \\
(6)\end{array}$ \\
\hline Measure of finance & $\begin{array}{l}-0.136 \\
(0.101)\end{array}$ & $\begin{array}{c}-0.161 \\
(0.139)\end{array}$ & $\begin{array}{c}-0.019^{* \star *} \\
(0.006)\end{array}$ & $\begin{array}{l}-0.024^{*} \\
(0.013)\end{array}$ & $\begin{array}{l}0.020^{\star *} \\
(0.009)\end{array}$ & $\begin{array}{c}0.012 \\
(0.009)\end{array}$ \\
\hline Investment rate & $\begin{array}{c}0.104 \\
(0.066)\end{array}$ & $\begin{array}{c}0.449^{*} \\
(0.272)\end{array}$ & $\begin{array}{c}0.131^{* * *} \\
(0.047)\end{array}$ & $\begin{array}{l}0.254^{* *} \\
(0.119)\end{array}$ & $\begin{array}{c}0.038 \\
(0.103)\end{array}$ & $\begin{array}{c}0.566^{\star * *} \\
(0.109)\end{array}$ \\
\hline School years & $\begin{array}{l}-0.116 \\
(0.238)\end{array}$ & $\begin{array}{c}0.477 \\
(0.512)\end{array}$ & $\begin{array}{l}-0.448^{*} \\
(0.226)\end{array}$ & $\begin{array}{l}-0.443 \\
(0.482)\end{array}$ & $\begin{array}{c}0.036 \\
(0.391)\end{array}$ & $\begin{array}{c}-0.142 \\
(0.321)\end{array}$ \\
\hline Population growth & $\begin{array}{l}-0.204 \\
(0.276)\end{array}$ & $\begin{array}{c}0.480 \\
(1.231)\end{array}$ & $\begin{array}{c}0.025 \\
(0.281)\end{array}$ & $\begin{array}{c}0.237 \\
(0.753)\end{array}$ & $\begin{array}{l}-0.381 \\
(0.456)\end{array}$ & $\begin{array}{c}-0.468 \\
(0.604)\end{array}$ \\
\hline In(Lagged GDP per capita) & $\begin{array}{l}-1.916 \\
(1.293)\end{array}$ & $\begin{array}{c}1.000 \\
(0.985)\end{array}$ & $\begin{array}{l}-2.029^{*} \\
(1.067)\end{array}$ & $\begin{array}{c}0.479 \\
(0.918)\end{array}$ & $\begin{array}{c}-3.774 \\
(3.243)\end{array}$ & $\begin{array}{c}-0.694 \\
(0.517)\end{array}$ \\
\hline Year fixed effects & Yes & Yes & Yes & Yes & Yes & Yes \\
\hline Linear country trends & No & No & No & No & No & No \\
\hline R-squared & 0.662 & - & 0.652 & - & 0.672 & - \\
\hline Hansen J-statistics & - & 8.33 & - & 8.54 & - & 3.07 \\
\hline Sample period & $1971-2010$ & $1971-2010$ & $1961-2010$ & $1961-2010$ & $1991-2010$ & $1991-2010$ \\
\hline Observations & 174 & 174 & 238 & 238 & 120 & 120 \\
\hline
\end{tabular}

Note: All regressions contain country fixed effects. Standard errors, which are shown in brackets, are clustered at the country-level in the OLS and robust using the Windmeijer (2005) finite-sample correction in the system GMM. ${ }^{* \star *}$ indicates significance at the $1 \%$ level, ${ }^{* \star}$ at the $5 \%$ level and ${ }^{*}$ at the $10 \%$ level. Value added of finance is financial and insurance activities divided by GDP, intermediated credit is credit to the non-financial private sector by financial institutions divided by GDP, and stock market capitalisation is the value of all shares listed in a stock market divided by GDP. Investment rate is gross fixed capital formation divided by GDP, school years is average years of schooling in the population aged 25 and over, and population growth is the growth rate of the population aged 15-64. The Hansen J-statistics use the overidentifying restrictions to test whether the instruments are valid. Toure: OECD Secretait calculations using

Source: OECD Secretariat calculations using OECD Structural Analysis database; World Bank Global Financial Development database; Bank for International Settlements credit series; Statistics Canada; OECD Economic Outlook database; R. J. Barro and J. W. Lee (2013), "A New Data Set of Educational Attainment in the World, 1950-2010", Journal of Development Economics, 104, pp. 184-198; World Bank World Development Indicators database. 
ECO/WKP(2015)41

\section{Investment}

26. Controlling for investment, as the baseline specification does, could mean that the estimated relationship between credit and growth does not account for a potentially important source of a positive effect of finance on growth: funding investment. However, re-estimating the equations reported in Table 2 without investment does not change the results in any material way, indicating that the role of credit in funding investment does not significantly diminish the negative link.

27. Empirical evidence suggests that overinvestment in housing represents one source of the negative link between intermediated credit and GDP growth. Residential construction averages $24 \%$ of total investment in OECD countries. The share of housing in total investment has been regressed on intermediated credit (as a ratio to GDP) and country and year fixed effects. The coefficient on intermediated credit is positive and statistically significant at the $10 \%$ level. ${ }^{5}$ A $10 \%$ of GDP increase in intermediated credit is associated with a 0.4 percentage points rise in the share of residential construction in total investment. This result goes in the same direction as Cecchetti and Kharroubi's (2015) finding that financial growth generally reduces productivity growth by encouraging projects that, such as in construction, generate low returns but provide easily pledgeable collateral.

\section{Innovation}

28. Innovation does not appear to influence the estimated relationships of finance with GDP growth (Table 7). Two measures of innovation, both common in the literature, are used: the natural logarithm of patent applications (Columns 1, 3 and 5) and business R\&D expenditure relative to GDP (Columns 2, 4 and 6). Fewer observations are available for $R \& D$ expenditure, which likely explains the lower significance of the $R \& D$ results for the value added of finance and stock market capitalisation. Innovation itself is not linked with GDP growth in most specifications.

\section{Labour share}

29. Finally, the results are robust to controlling for the share of capital in total income (Table 8). This is to address the concern that the negative link of financial sector value added and intermediated credit with GDP growth might simply be capturing that growth slows down after a lot of capital has been accumulated. The inclusion of the labour share reduces the sample size substantially. Nonetheless, the size and significance of the coefficient of interest do not change materially in the baseline regressions when not controlling for the labour share but restricting the sample to observations for which the labour share is available (Columns 1, 3 and 5). When the labour share is controlled for, the results are very similar. The labour share itself is negatively (statistically significant at the $1 \%$ level) related with GDP growth (Columns 2, 4 and 6). This suggests that, contrary to what was conjectured, a higher capital stock actually promotes long-term growth.

\section{Outlier observations}

30. As additional robustness checks, alternative regressions have been run for each indicator of financial size by dropping countries one at a time. The results are virtually unchanged, indicating that they are not driven by an outlier.

5. Regressing the share of housing investment in total investment (\%) on intermediated credit (\% of GDP), plus country and year fixed effects, yields a coefficient of 0.039 and a p-value of 0.088 (clustering the standard errors by country). The number of observations is 1253 and the R-squared 0.701 . 
Table 7. The role of innovation for the finance and growth relationship

\begin{tabular}{|c|c|c|c|c|c|c|}
\hline \multirow{3}{*}{$\begin{array}{l}\text { Dependent variable: } \\
\text { Measure of finance: }\end{array}$} & \multicolumn{6}{|c|}{ GDP growth per capita } \\
\hline & \multicolumn{2}{|c|}{ Value added of finance } & \multicolumn{2}{|c|}{ Intermediated credit } & \multicolumn{2}{|c|}{ Stock market capitalisation } \\
\hline & $(1)$ & $(2)$ & $(3)$ & $(4)$ & $(5)$ & $(6)$ \\
\hline Measure of finance & $\begin{array}{c}-0.257^{\star \star} \\
(0.121)\end{array}$ & $\begin{array}{c}-0.223 \\
(0.284)\end{array}$ & $\begin{array}{c}-0.034^{\star \star \star} \\
(0.009)\end{array}$ & $\begin{array}{c}-0.062^{* \star *} \\
(0.017)\end{array}$ & $\begin{array}{c}0.018^{\star \star \star} \\
(0.005)\end{array}$ & $\begin{array}{c}0.019^{*} \\
(0.009)\end{array}$ \\
\hline Investment rate & $\begin{array}{c}0.184^{* * *} \\
(0.058)\end{array}$ & $\begin{array}{l}0.221^{*} \\
(0.111)\end{array}$ & $\begin{array}{c}0.282^{* * *} \\
(0.061)\end{array}$ & $\begin{array}{l}0.230^{*} \\
(0.119)\end{array}$ & $\begin{array}{c}0.275^{\star \star *} \\
(0.074)\end{array}$ & $\begin{array}{l}0.284^{* *} \\
(0.129)\end{array}$ \\
\hline School years & $\begin{array}{c}1.664 \\
(1.021)\end{array}$ & $\begin{array}{c}1.663 \\
(1.303)\end{array}$ & $\begin{array}{c}0.233 \\
(0.808)\end{array}$ & $\begin{array}{l}-0.416 \\
(1.074)\end{array}$ & $\begin{array}{c}0.816 \\
(1.162)\end{array}$ & $\begin{array}{c}1.586 \\
(1.364)\end{array}$ \\
\hline Population growth & $\begin{array}{c}-0.255 \\
(0.236)\end{array}$ & $\begin{array}{c}-1.021^{* *} \\
(0.379)\end{array}$ & $\begin{array}{l}-0.235 \\
(0.213)\end{array}$ & $\begin{array}{c}-0.863^{*} \\
(0.487)\end{array}$ & $\begin{array}{l}-0.462 \\
(0.393)\end{array}$ & $\begin{array}{l}-0.484 \\
(0.589)\end{array}$ \\
\hline In(Patents) & $\begin{array}{c}0.240 \\
(0.307)\end{array}$ & - & $\begin{array}{c}0.112 \\
(0.271)\end{array}$ & - & $\begin{array}{l}-0.147 \\
(0.535)\end{array}$ & - \\
\hline R\&D expenditure & - & $\begin{array}{l}4.720^{* *} \\
(2.186)\end{array}$ & - & $\begin{array}{c}1.244 \\
(1.686)\end{array}$ & - & $\begin{array}{c}0.997 \\
(1.955)\end{array}$ \\
\hline Year fixed effects & Yes & Yes & Yes & Yes & Yes & Yes \\
\hline Linear country trends & Yes & Yes & Yes & Yes & Yes & Yes \\
\hline R-squared & 0.591 & 0.644 & 0.534 & 0.662 & 0.597 & 0.649 \\
\hline Sample period & $1977-2011$ & $1987-2011$ & 1977-2011 & $1987-2011$ & $1989-2011$ & $1989-2011$ \\
\hline Observations & 861 & 372 & 956 & 389 & 701 & 383 \\
\hline
\end{tabular}

Note: All regressions are OLS and contain country fixed effects. Standard errors, which are shown in brackets, are clustered at the country-level. ${ }^{\star \star \star}$ indicates significance at the $1 \%$ level, ${ }^{*}$ at the $5 \%$ level and ${ }^{*}$ at the $10 \%$ level. Value added of finance is financial and insurance activities divided by GDP, intermediated credit is credit to the non-financial private sector by financial institutions divided by GDP, and stock market capitalisation is the value of all shares listed in a stock market divided by GDP. Investment rate is gross fixed capital sector by financial institutions divided by GDP, and stock market capitalisation is the value of all shares listed in a stock market divided by GDP. Investment rate is gross fixed capital formation divided by GDP, school years is average years of schooling in the population aged 25 and over, and population growth is the growth rate of the population aged $15-64$.
In(Patents) is the natural logarithm of patent applications in the applicant's country of residence, and R\&D expenditure is business enterprise R\&D expenditure divided by GDP. The sample covers OECD countries.

Source: OECD Secretariat calculations using OECD Structural Analysis database; World Bank Global Financial Development database; Bank for International Settlements credit series; Statistics Canada; World Bank World Development Indicators database; OECD Economic Outlook database; R. J. Barro and J. W. Lee (2013), "A New Data Set of Educational Attainment in the World, 1950-2010", Journal of Development Economics, 104, pp. 184-198; OECD Patent database; OECD Analytical Business Enterprise Research and Development database. 
Table 8. The role of the labour share for the finance and growth relationship

\begin{tabular}{|c|c|c|c|c|c|c|}
\hline \multirow{3}{*}{$\begin{array}{l}\text { Dependent variable: } \\
\text { Measure of finance: }\end{array}$} & \multicolumn{6}{|c|}{ GDP growth per capita } \\
\hline & \multicolumn{2}{|c|}{ Value added of finance } & \multicolumn{2}{|c|}{ Intermediated credit } & \multicolumn{2}{|c|}{ Stock market capitalisation } \\
\hline & $(1)$ & (2) & (3) & (4) & (5) & $(6)$ \\
\hline Measure of finance & $\begin{array}{l}-0.284^{\star \star} \\
(0.132)\end{array}$ & $\begin{array}{l}-0.297^{\star \star} \\
(0.108)\end{array}$ & $\begin{array}{c}-0.034^{\star \star \star} \\
(0.008)\end{array}$ & $\begin{array}{c}-0.036^{\star \star \star} \\
(0.007)\end{array}$ & $\begin{array}{l}0.020^{\star \star} \\
(0.008)\end{array}$ & $\begin{array}{l}0.015^{\star} \\
(0.008)\end{array}$ \\
\hline Investment rate & $\begin{array}{l}0.124^{\star \star *} \\
(0.038)\end{array}$ & $\begin{array}{c}0.173^{\star \star \star} \\
(0.052)\end{array}$ & $\begin{array}{c}0.162^{\star * *} \\
(0.043)\end{array}$ & $\begin{array}{c}0.204^{* * *} \\
(0.047)\end{array}$ & $\begin{array}{l}0.145^{\star} \\
(0.072)\end{array}$ & $\begin{array}{c}0.212^{\star * *} \\
(0.071)\end{array}$ \\
\hline School years & $\begin{array}{l}1.391^{*} \\
(0.762)\end{array}$ & $\begin{array}{c}0.987 \\
(0.712)\end{array}$ & $\begin{array}{l}-0.045 \\
(0.455)\end{array}$ & $\begin{array}{l}-0.321 \\
(0.399)\end{array}$ & $\begin{array}{c}0.154 \\
(1.216)\end{array}$ & $\begin{array}{c}-0.368 \\
(1.302)\end{array}$ \\
\hline Population growth & $\begin{array}{l}-0.022 \\
(0.223)\end{array}$ & $\begin{array}{c}0.113 \\
(0.280)\end{array}$ & $\begin{array}{l}-0.981^{*} \\
(0.533)\end{array}$ & $\begin{array}{l}-0.803 \\
(0.494)\end{array}$ & $\begin{array}{l}-0.135 \\
(0.407)\end{array}$ & $\begin{array}{l}-0.068 \\
(0.427)\end{array}$ \\
\hline Labour share & - & $\begin{array}{c}-0.197^{* \star *} \\
(0.057)\end{array}$ & - & $\begin{array}{c}-0.187^{* \star *} \\
(0.048)\end{array}$ & - & $\begin{array}{c}-0.338^{* * *} \\
(0.098)\end{array}$ \\
\hline Year fixed effects & Yes & Yes & Yes & Yes & Yes & Yes \\
\hline Linear country trends & Yes & Yes & Yes & Yes & Yes & Yes \\
\hline R-squared & 0.608 & 0.626 & 0.614 & 0.631 & 0.677 & 0.711 \\
\hline Sample period & $1970-2010$ & $1970-2010$ & $1961-2010$ & $1961-2010$ & $1989-2010$ & $1989-2010$ \\
\hline Observations & 700 & 700 & 782 & 782 & 464 & 464 \\
\hline
\end{tabular}

Note: All regressions are OLS and contain country fixed effects. Standard errors, which are shown in brackets, are clustered at the country-level. *** indicates significance at the $1 \%$ level, ${ }^{* *}$ at the $5 \%$ level and ${ }^{*}$ at the $10 \%$ level. Value added of finance is financial and insurance activities divided by GDP, intermediated credit is credit to the non-financial private sector by financial institutions divided by GDP, and stock market capitalisation is the value of all shares listed in a stock market divided by GDP. Investment rate is gross fixed capital formation divided by GDP, school years is average years of schooling in the population aged 25 and over, population growth is the growth rate of the population aged 15-64, and labour share is labour compensation divided by GDP. The sample covers OECD countries.

Source: OECD Secretariat calculations using OECD Structural Analysis database; World Bank Global Financial Development database; Bank for International Settlements credit series; Statistics Canada; OECD Economic Outlook database; R. J. Barro and J. W. Lee (2013), "A New Data Set of Educational Attainment in the World, 1950-2010", Journal of Development Economics, 104, pp. 184-198; World Bank World Development Indicators database; EU-KLEMS database; WORLD-KLEMS database. 


\section{Heterogeneities in the finance and growth relationship}

31. This section investigates the extent to which the finance and growth links are heterogeneous, first across different countries and then across different levels of financial development.

32. Allowing for differences in the finance and growth relationship between countries shows that the country-specific coefficients mostly have the same sign as the average estimates (Table 9). The baseline specification with country-specific linear time trends in Column 4 of Table 1 and Column 5 of Tables 2-3 is modified by interacting the measure of finance with a set of country fixed effects. One notable finding is that the association between intermediated credit and GDP growth is significantly negative for 26 of the 42 OECD and G20 countries (Column 2). Chile, India, South Africa and Turkey - four countries characterised by comparatively low levels of economic development over the sample period - are the only ones with a significantly positive link. The positive links for this group of countries are estimated over the full period for which data are available, which leaves open the possibility that strong credit increases in recent years may threaten growth, a risk which appears relevant in Turkey (OECD, 2014).

33. As regards differences between levels of financial development, no evidence is found of a quadratic relationship with GDP growth for the value added of finance and intermediated credit (Table 10). The specification used for this purpose is the one without country-specific linear time trends, as abovetrend indebtedness is unlikely to be conducive to durably higher growth even at low levels of finance. The regressions in Columns 2 and 3 of Tables 1 and 2 (excluding and including year fixed effects) are re-run with the squared value of the measure of finance. This yields estimates on the quadratic term that are clearly insignificant (Columns 1-4). By contrast, testing for such non-linearities reveals a hump-shaped association between stock market capitalisation and GDP growth. Their correlation becomes negative beyond a certain level of stock market capitalisation (Columns 5 and 6). However, the maximum is at about $210 \%$ of GDP which only Luxembourg and Switzerland exceeded several times over the sample period.

34. To further investigate the role of the level of finance for the finance and growth relationship, multiple regressions (in the specification without country-specific linear time trends) are run consecutively including observations with higher levels of value added (Figure 4). Along the horizontal axis the number of observations and also the average level for the value added of finance increase. As the value added of finance increases, the point estimate converges to the average estimate identified in Column 3 of Table $1{ }^{6}$ The link between the value added of finance and GDP growth is positive for low levels of value added, but not in a statistically significant fashion (as indicated by the $90 \%$ confidence band). The point estimate becomes negative and significant at 5-6\% of GDP. Extreme observations from international financial centres then reduce the absolute value of the point estimate at high levels of financial sector value added.

6. The full convergence occurs outside the range plotted in Figure 4. 
Table 9. The finance and growth relationships for individual OECD and G20 countries

\begin{tabular}{|c|c|c|c|}
\hline Measure of finance: & $\begin{array}{l}\text { Value added of } \\
\text { finance } \\
\text { (1) }\end{array}$ & $\begin{array}{l}\text { Intermediated } \\
\text { credit } \\
(2)\end{array}$ & $\begin{array}{c}\text { Stock market } \\
\text { capitalisation } \\
\text { (3) }\end{array}$ \\
\hline Argentina & . & -- & -- \\
\hline Australia & - & - & -- \\
\hline Austria & -- & + & ++ \\
\hline Belgium & - & - & + \\
\hline Brazil & . & + & ++ \\
\hline Canada & ++ & -- & ++ \\
\hline Chile & + & ++ & - \\
\hline China & . & -- & ++ \\
\hline Czech Republic & - & -- & ++ \\
\hline Denmark & - & -- & + \\
\hline Estonia & -- & -- & ++ \\
\hline Finland & - & -- & ++ \\
\hline France & + & - & + \\
\hline Germany & -- & - & + \\
\hline Greece & -- & -- & ++ \\
\hline Hungary & -- & -- & + \\
\hline Iceland & - & + & + \\
\hline India & . & ++ & - \\
\hline Indonesia & . & -- & -- \\
\hline Ireland & -- & -- & - \\
\hline Israel & . & -- & ++ \\
\hline Italy & - & -- & + \\
\hline Japan & + & -- & ++ \\
\hline Korea & -- & - & ++ \\
\hline Luxembourg & -- & -- & ++ \\
\hline Mexico & -- & - & + \\
\hline Netherlands & -- & - & + \\
\hline New Zealand & -- & - & ++ \\
\hline Norway & -- & -- & -- \\
\hline Poland & -- & -- & + \\
\hline Portugal & ++ & -- & ++ \\
\hline Russian Federation & . & -- & ++ \\
\hline Saudi Arabia & . & -- & ++ \\
\hline Slovak Republic & ++ & -- & ++ \\
\hline Slovenia & -- & -- & ++ \\
\hline South Africa & . & ++ & - \\
\hline Spain & ++ & -- & + \\
\hline Sweden & -- & -- & ++ \\
\hline Switzerland & + & -- & ++ \\
\hline Turkey & . & ++ & -- \\
\hline United Kingdom & -- & -- & ++ \\
\hline United States & - & - & + \\
\hline
\end{tabular}

Note: Entries indicate the sign of the coefficient in a regression of GDP growth per capita on the measure of finance. One sign ("+"/“-") indicates no significance at the $10 \%$ level, two signs ("++"|"--") significance at the $10 \%$ level, and "." means no observation is available. Value added of finance is financial and insurance activities divided by GDP, intermediated credit is credit to the nonfinancial private sector by financial institutions divided by GDP, and stock market capitalisation is the value of all shares listed in a stock market divided by GDP. The specification, control variables and sample are the same as in Column 4 of Table 1 and Column 5 of Tables 2-3. In each case, the measure of finance is interacted with a set of country fixed effects to allow for cross-country heterogeneity in the finance and growth relationship.

Source: OECD Secretariat calculations using OECD Structural Analysis database; World Bank Global Financial Development database; Bank for International Settlements credit series; Statistics Canada; World Bank World Development Indicators database; OECD Economic Outlook database; R. J. Barro and J. W. Lee (2013), "A New Data Set of Educational Attainment in the World, 19502010", Journal of Development Economics, 104, pp. 184-198. 
Table 10. Testing for a quadratic relationship between finance and GDP growth per capita

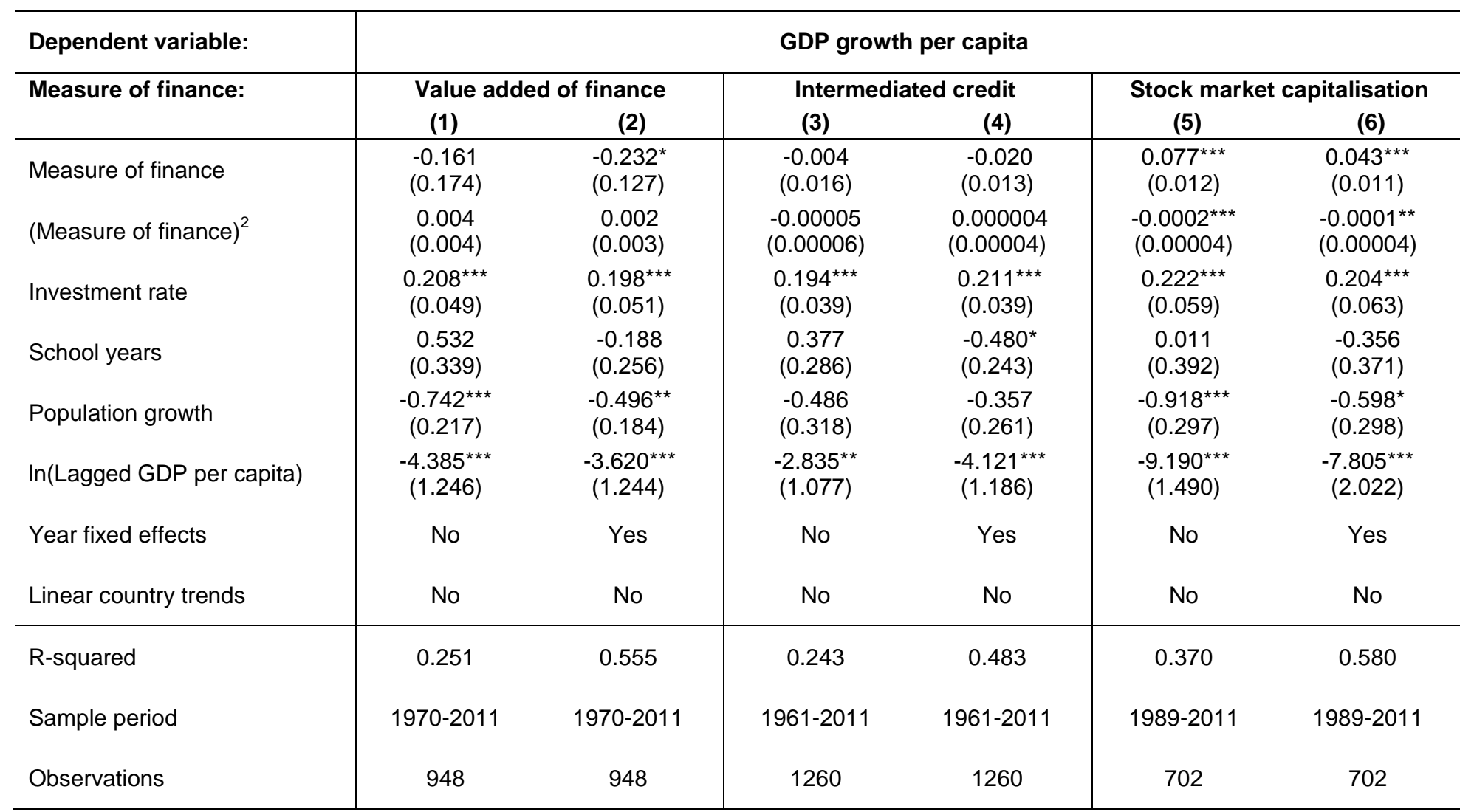

Note: All regressions are OLS and contain country fixed effects. Standard errors, which are shown in brackets, are clustered at the country-level. ${ }^{* * *}$ indicates significance at the $1 \%$ level, ${ }^{* *}$ at the $5 \%$ level and * at the $10 \%$ level. Value added of finance is financial and insurance activities divided by GDP, intermediated credit is credit to the non-financial private sector by financial institutions divided by GDP, and stock market capitalisation is the value of all shares listed in a stock market divided by GDP. Investment rate is gross fixed capital formation divided by GDP, school years is average years of schooling in the population aged 25 and over, and population growth is the growth rate of the population aged 15-64. The sample covers 29-30 OECD countries.

Source: OECD Secretariat calculations using OECD Structural Analysis database; World Bank Global Financial Development database; Bank for International Settlements credit series; Statistics Canada; World Bank World Development Indicators database; OECD Economic Outlook database; R. J. Barro and J. W. Lee (2013), "A New Data Set of Educational Attainment in the World, 1950-2010", Journal of Development Economics, 104, pp. 184-198. 
Figure 4. The varying association between the value added of finance and GDP growth per capita

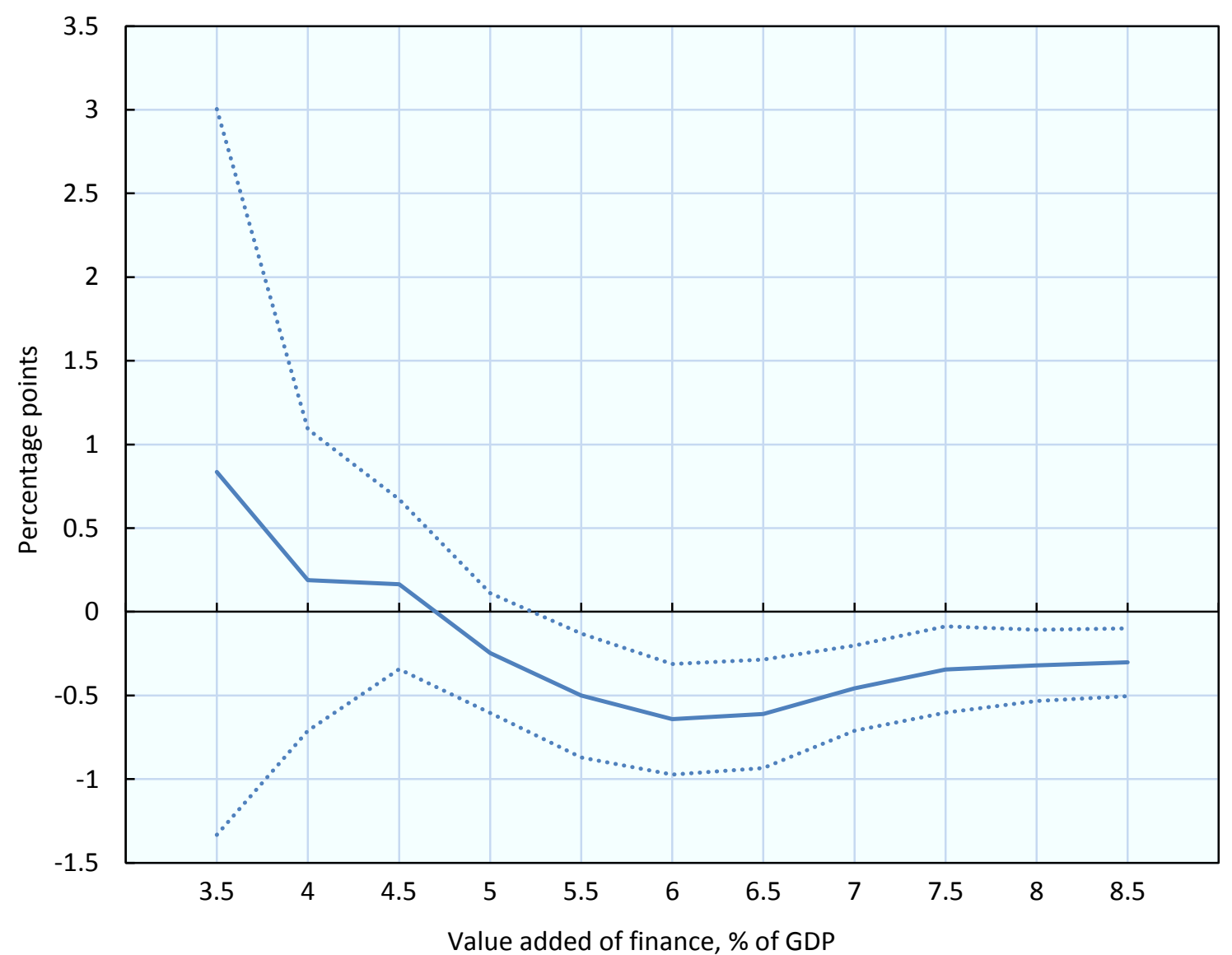

Note: Value added of finance is financial and insurance activities. Estimates are obtained by consecutively including observations with higher levels of the value added of finance in Column 3 of Table 1 . The dotted lines represent the $90 \%$ confidence band. The sample covers 32 OECD countries.

Source: OECD Secretariat calculations using OECD Structural Analysis database; World Bank World Development Indicators database; OECD Economic Outlook database; R. J. Barro and J. W. Lee (2013), "A New Data Set of Educational Attainment in the World, 1950-2010", Journal of Development Economics, 104, pp. 184-198.

35. The same exercise is conducted for intermediated credit (Figure 5). At low levels of credit, the link with GDP growth is statistically significant, positive and large. The coefficient becomes statistically insignificant and then significantly negative when bringing in observations with higher levels of credit. The finding of a significantly negative relationship between finance and growth when including observations where intermediated credit is $100 \%$ of GDP or more is broadly consistent with other recent research (Arcand et al., 2012; Beck et al., 2014; Cecchetti and Kharroubi, 2012; Law and Singh, 2014). In larger samples of advanced, middle-income and developing countries, these studies identify a threshold for intermediated credit of about $90 \%$ of GDP, above which it exhibits a negative relationship with GDP growth. 
ECO/WKP(2015)41

Figure 5. The positive then negative association between intermediated credit and GDP growth per capita

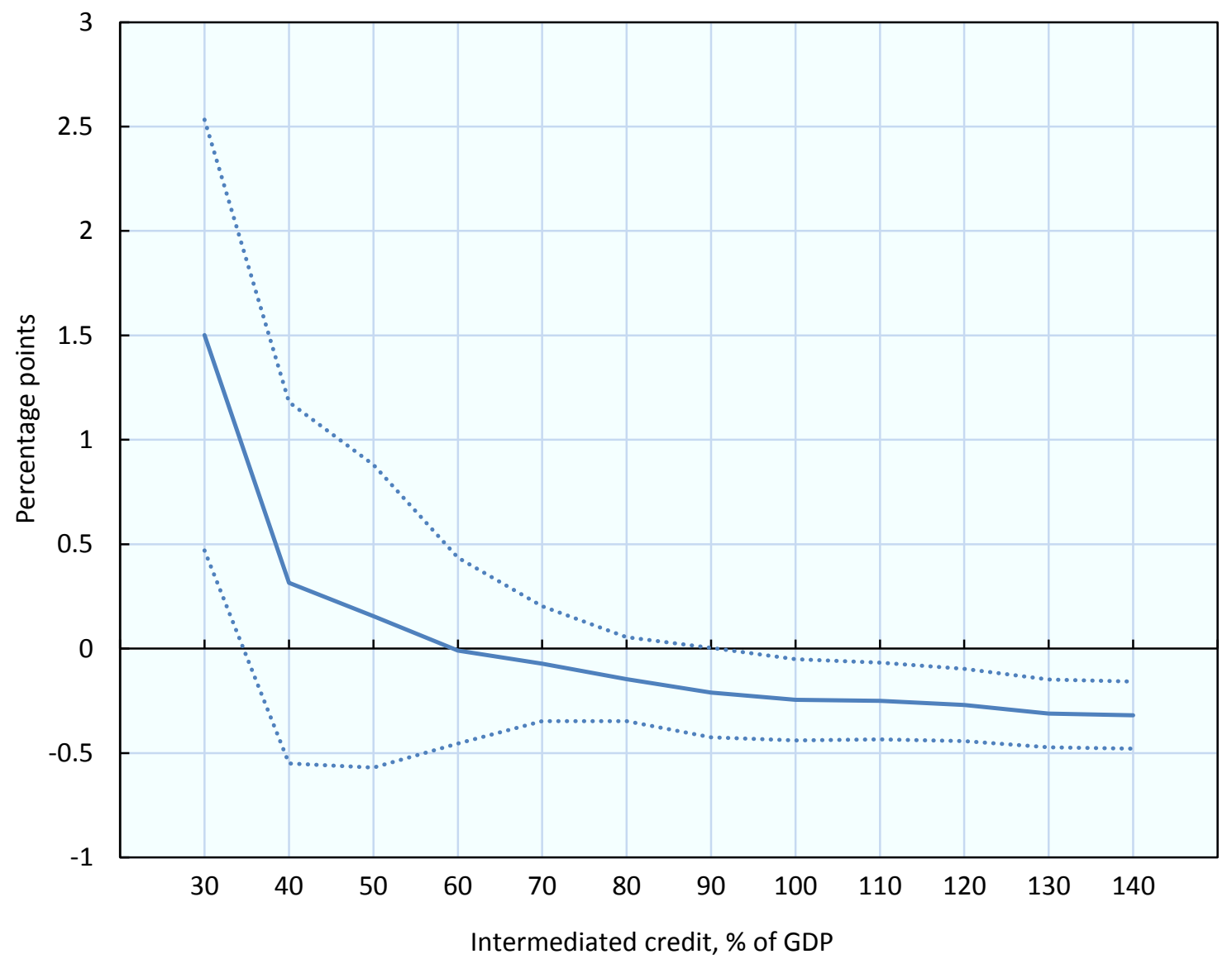

Note: Intermediated credit is credit to the non-financial private sector by financial institutions. Estimates are obtained by consecutively including observations with higher levels of intermediated credit in Column 3 of Table 2 . The dotted lines represent the $90 \%$ confidence band. The sample covers 33 OECD countries.

Source: OECD Secretariat calculations using World Bank Global Financial Development database; Bank for International Settlements credit series; Statistics Canada; World Bank World Development Indicators database; OECD Economic Outlook database; R. J. Barro and J. W. Lee (2013), "A New Data Set of Educational Attainment in the World, 1950-2010", Journal of Development Economics, 104, pp. 184-198.

36. Similarly, increases from an already very high level of stock market capitalisation exhibit a negative link with GDP growth (Figure 6), even though their relationship over the full sample is positive. The consecutive inclusion of observations with lower levels of stock market capitalisation continuously increases the coefficient. The estimate turns statistically insignificant (at the 10\% level) at 100\% of GDP. This $100 \%$ threshold is lower than the peak identified in the regression with the squared value of stock market capitalisation in Column 6 of Table 10. The 100\% threshold is likely to be more reliable than this peak because restricting the sample to observations with high levels of stock market capitalisation enables a much more precise characterisation of the finance and growth link in countries with very deep stock markets. 
Figure 6. The positive then negative association between stock market capitalisation and GDP growth per capita

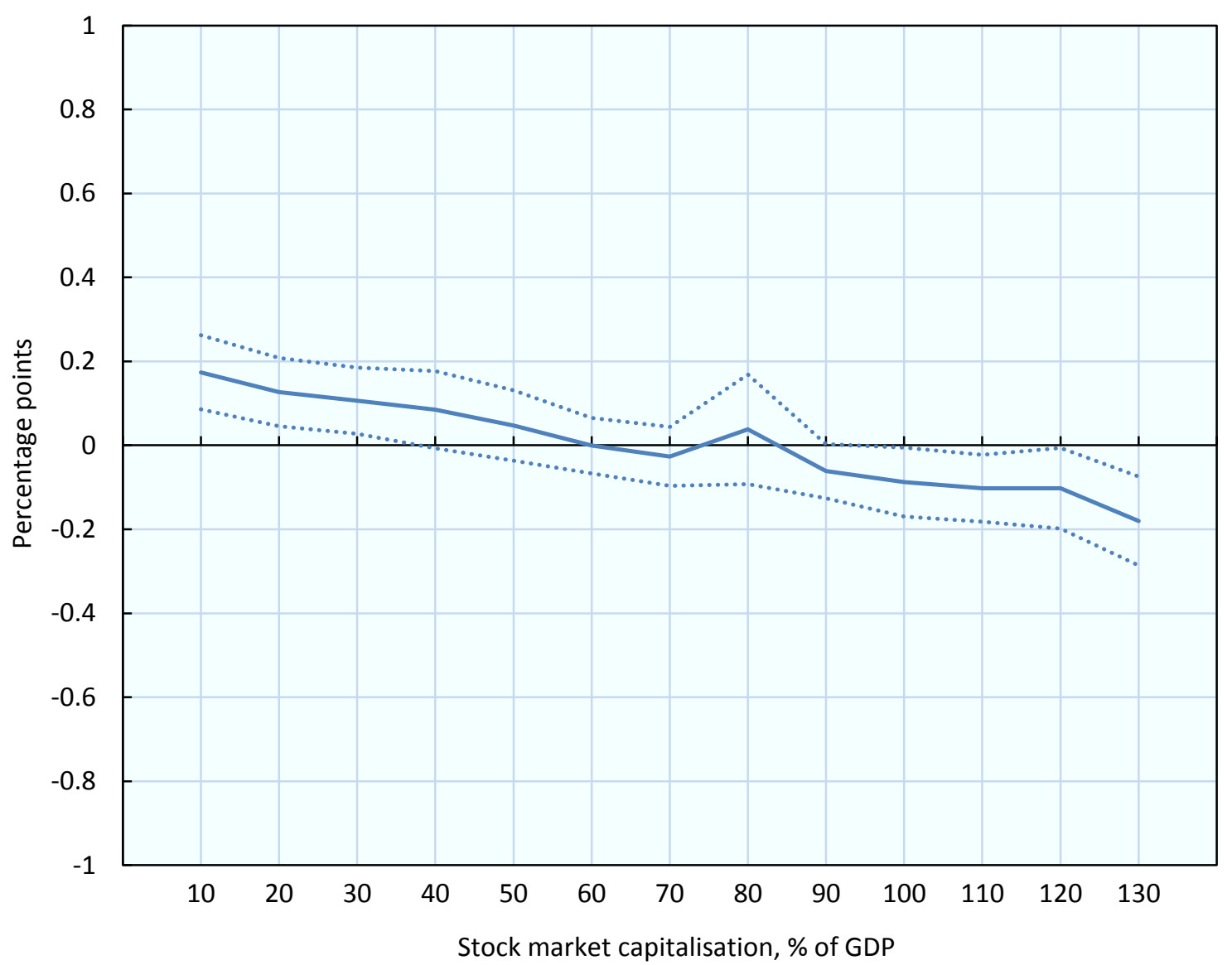

Note: Stock market capitalisation is the value of all shares listed in a stock market. Estimates are obtained by consecutively including observations with lower levels of stock market capitalisation in Column 3 of Table 3 . The dotted lines represent the $90 \%$ confidence band. The sample covers all OECD countries.

Source: OECD Secretariat calculations using World Bank Global Financial Development database; World Bank World Development Indicators database; OECD Economic Outlook database; R. J. Barro and J. W. Lee (2013), "A New Data Set of Educational Attainment in the World, 1950-2010", Journal of Development Economics, 104, pp. 184-198.

37. These thresholds are estimated to apply on average in OECD countries and only take into account country specificities through the exogenous covariates and country fixed effects. The specification does not allow the threshold itself to depend on country specificities, including the design of economic and financial institutions, which may increase or decrease the threshold in some countries relative to others. Estimating thresholds depending on country characteristics or even country-specific thresholds is difficult empirically given the limited variation across the 34 OECD countries. This question is left for future research. What can be said from the evidence is that countries with more intermediated credit and larger stock markets, i.e. countries further to the north-east in Figure 7, are more likely to be in the region where further financial expansion harms growth. If the 100\% of GDP threshold is applied uniformly to all OECD countries despite national specificities, 21 are above it for intermediated credit but only 8 for stock market capitalisation. 
ECO/WKP(2015)41

Figure 7. Intermediated credit and stock market capitalisation in OECD and G20 countries

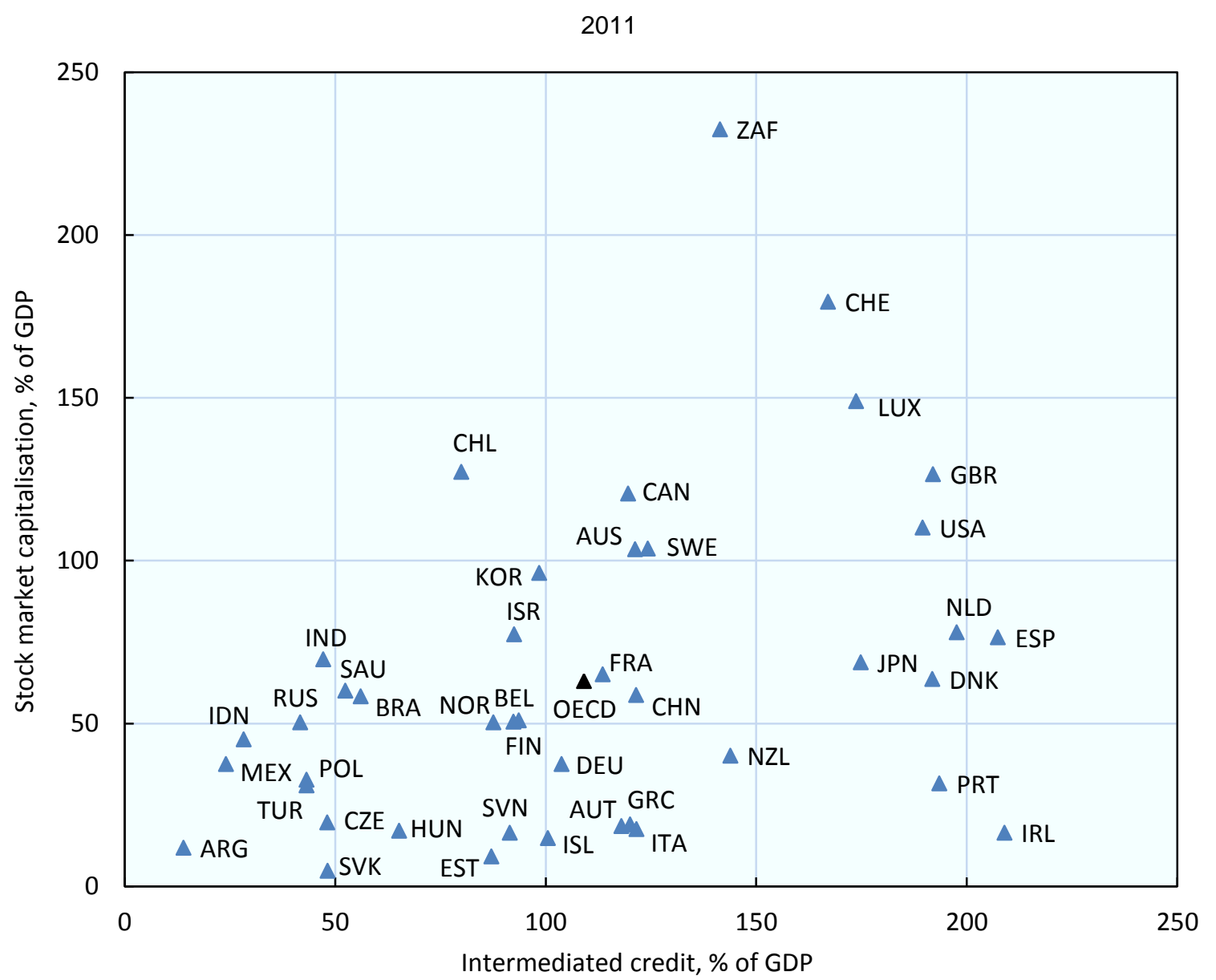

Note: Intermediated credit is credit to the non-financial private sector by financial institutions, and stock market capitalisation is the value of all shares listed in a stock market. OECD is the simple average of OECD countries. For New Zealand, the data point is for 2010.

Source: World Bank Global Financial Development database; Bank for International Settlements credit series; Statistics Canada.

\section{Causality}

38. This section investigates causation in the link from finance to growth. It employs two identification strategies: one yet unexplored in the literature and standard generalised method of moments (GMM). For the novel strategy, changes in financial regulation across countries and time, which induced plausibly exogenous variation in financial size, serve as instruments. The first part of the section analyses the link between financial deregulation and financial size. While important in itself, this relationship also provides the first stage of the instrumental variables (IV) estimation that analyses whether finance causes growth. The second part of the section discusses the second-stage IV results and the third part the findings from the GMM. 


\subsection{Mapping the effect of financial deregulation on financial size}

39. Regulation strongly influences the financial sector. The United States provides a prominent example over the 1970-80s period, during which states liberalised intrastate branching. Relying on the arguably exogenous differences in the timing of implementation, Jayaratne and Strahan (1996) show that deregulation improved the quality of bank lending without increasing its volume. Black and Strahan (2002) emphasise that this financial deregulation episode contributed to the nationwide consolidation of the banking industry and dramatically reduced the role of small banks. In a cross-country study, de Serres et al. (2006) find that financial deregulation relaxing bankruptcy procedures, reducing barriers to entry, diminishing government control of banks and improving contract enforcement was associated with stronger growth in sectors where firms are comparatively more dependent on external sources of funding.

40. This subsection investigates the effect of financial deregulation on financial size. It uses the IMF financial reform index published by Abiad et al. (2010). This index measures the country-wide degree of financial regulation, normalised to vary from 0 (stringent) to 1 (lax), for every year over the 1973-2005 period. The index combines financial regulation policies along seven dimensions: $i$ ) credit controls and reserve requirements, ii) interest rate controls, iii) entry barriers, iv) state ownership, $v$ ) securities market policies, vi) banking regulations and vii) restrictions on the financial account. It shows that all OECD and G20 countries relaxed financial regulation over the three decades to 2005 .

41. Simple bivariate relationships reveal a positive link between financial deregulation and indicators of financial size. More value added of finance, intermediated credit and stock market capitalisation are all correlated with less stringent financial regulation (Figures 8-10). Table 11 presents the regression results including country fixed effects. The three links hold in a statistically significant fashion with a confidence level of above 99.9\% (Columns 1, 3 and 5). These correlations in levels reflect that financial deregulation occurred in a period of trend financial expansion. While these two trends could have been driven by a third one, one way of eliminating this concern is to control for country-specific linear time trends, as was done for similar reasons in most growth regressions above. However, this approach by design cannot detect causal links from trend financial deregulation to trend financial expansion.

42. When year fixed effects and country-specific linear time trends are included in the regressions, the coefficient on the financial deregulation indicator continues to be significantly positive for the value added of finance, is statistically insignificant from zero for intermediated credit and becomes significantly negative for stock market expansions (Columns 2, 4 and 6). The two results on stock market capitalisation taken together mean that stock markets tend to be larger when financial markets are more deregulated. However, in the specifications with year fixed effects, which thereby account for the global dot-com boomand-bust cycle, financial deregulation in a given country is, on average, associated with relatively small stock markets in this country. This result seems sensible: If financial deregulation encourages the development of large bubbles which burst after a short period of time, deviations from average stock market levels in a certain year are expected to be more often negative in countries with more deregulated financial markets. This is precisely what is the case in the available data, which include both the build-up (from the early to mid-1990s) and the crash (from the early to mid-2000s) of the late 1990s bubble. 
ECO/WKP(2015)41

Figure 8. The bivariate relationship between financial deregulation and the value added of finance

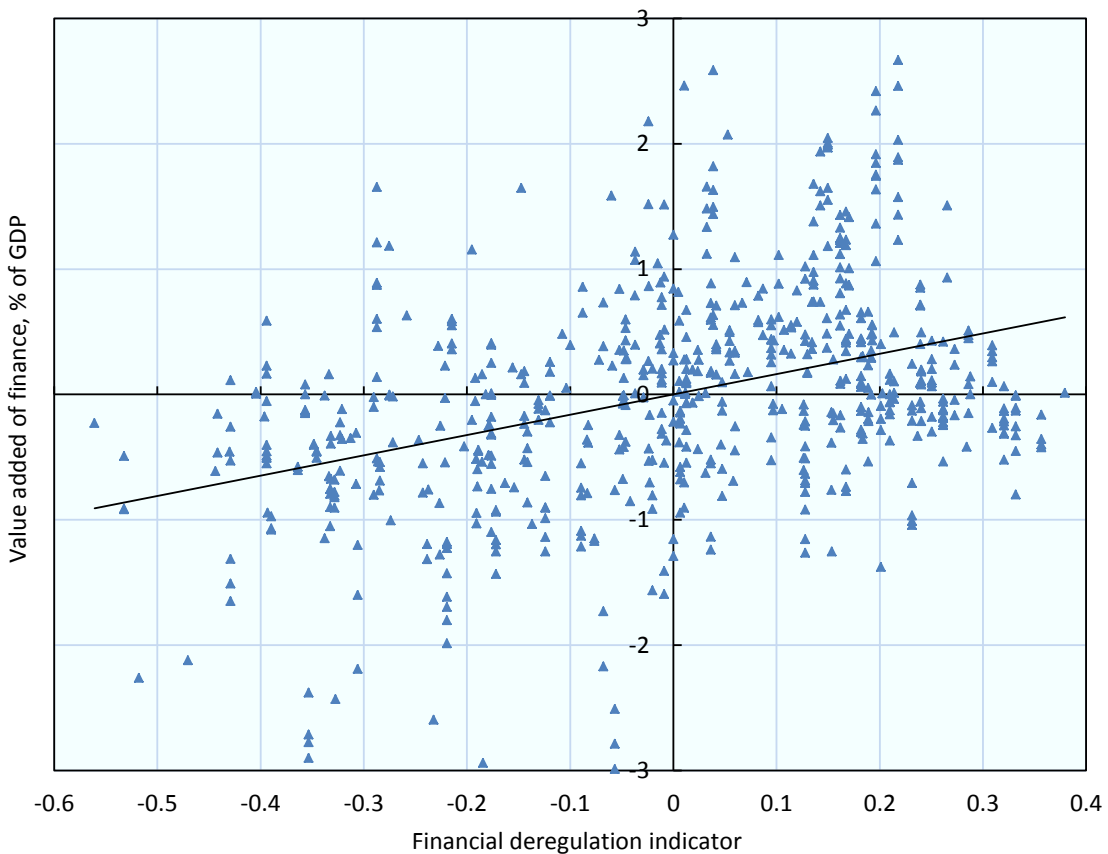

Note: The sample covers 28 OECD countries between 1973 and 2005. The line indicates the fitted values of an OLS regression through the data points. The two variables are demeaned using the respective country means to average out differences between countries that are persistent over time.

Source: A. Abiad, E. Detragiache and T. Tressel (2010), "A New Database of Financial Reforms", IMF Staff Papers, 75(2), pp. 281302; OECD Structural Analysis database; OECD Secretariat calculations.

Figure 9. The bivariate relationship between financial deregulation and intermediated credit

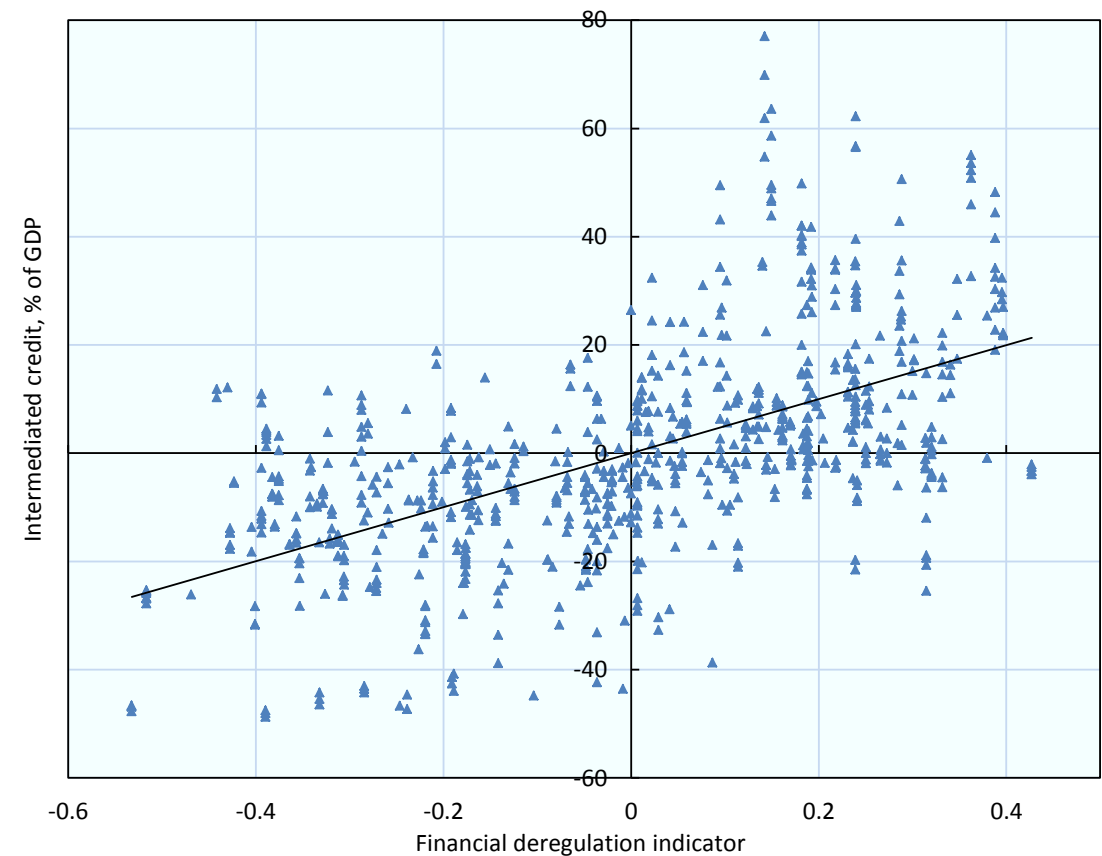

Note: The sample covers 29 OECD countries between 1973 and 2005. The line indicates the fitted values of an OLS regression through the data points. The two variables are demeaned using the respective country means to average out differences between countries that are persistent over time.

Source: A. Abiad, E. Detragiache and T. Tressel (2010), "A New Database of Financial Reforms", IMF Staff Papers, 75(2), pp. 281302; World Bank Global Financial Development database; Bank for International Settlements credit series; Statistics Canada; OECD Secretariat calculations. 
ECO/WKP(2015)41

Figure 10. The bivariate relationship between financial deregulation and stock market capitalisation

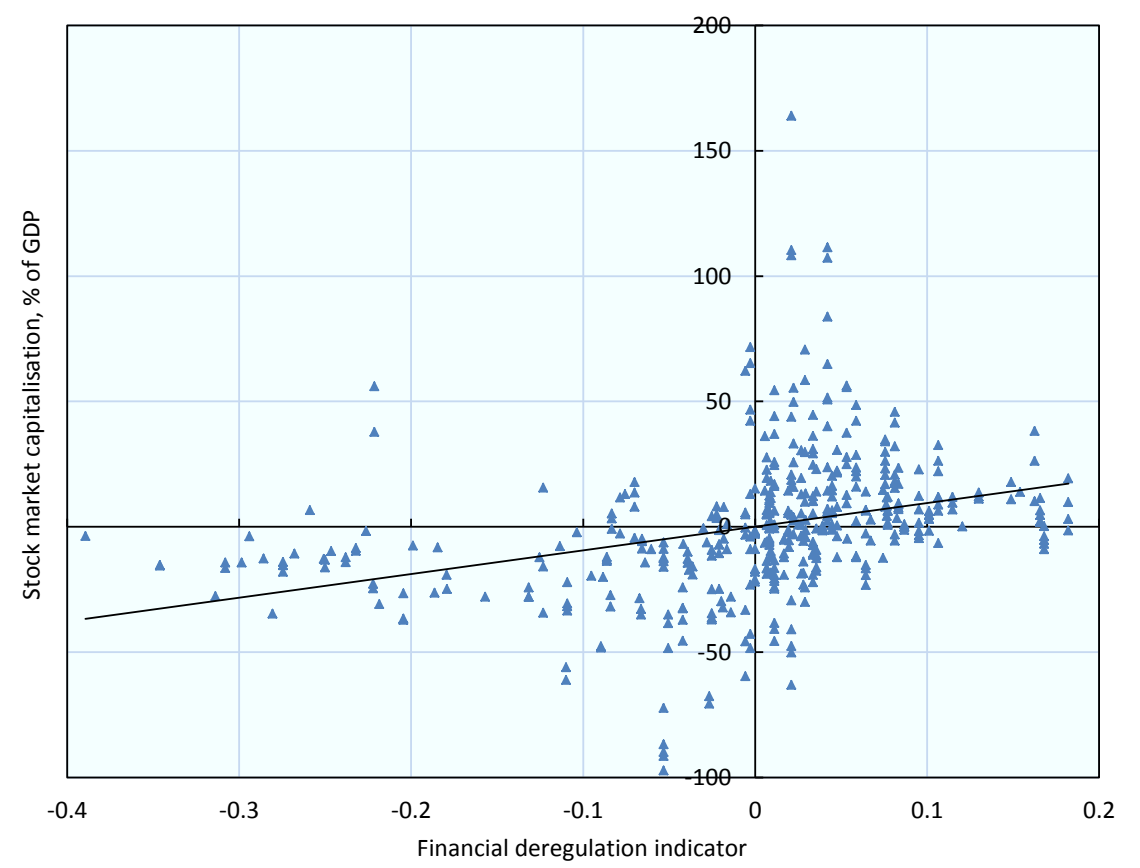

Note: The sample covers 29 OECD countries between 1989 and 2005. The line indicates the fitted values of an OLS regression through the data points. The two variables are demeaned using the respective country means to average out differences between countries that are persistent over time.

Source: A. Abiad, E. Detragiache and T. Tressel (2010), "A New Database of Financial Reforms", IMF Staff Papers, 75(2), pp. 281302; World Bank Global Financial Development database; OECD Secretariat calculations. 
Table 11. The relationship between financial deregulation and financial size

\begin{tabular}{|c|c|c|c|c|c|c|}
\hline \multirow[t]{2}{*}{ Dependent variable: } & \multicolumn{2}{|c|}{ Value added of finance } & \multicolumn{2}{|c|}{ Intermediated credit } & \multicolumn{2}{|c|}{ Stock market capitalisation } \\
\hline & (1) & (2) & (3) & (4) & (5) & (6) \\
\hline Financial deregulation & $\begin{array}{c}1.690^{\star * *} \\
(0.519)\end{array}$ & $\begin{array}{c}1.135^{\star} \\
(0.642)\end{array}$ & $\begin{array}{c}50.635^{\star * \star} \\
(8.741)\end{array}$ & $\begin{array}{c}5.797 \\
(11.009)\end{array}$ & $\begin{array}{c}93.668^{\star \star \star} \\
(21.329)\end{array}$ & $\begin{array}{c}-74.204^{* * *} \\
(25.966)\end{array}$ \\
\hline Year fixed effects & No & Yes & No & Yes & No & Yes \\
\hline Linear country trends & No & Yes & No & Yes & No & Yes \\
\hline R-squared & 0.741 & 0.909 & 0.831 & 0.943 & 0.664 & 0.905 \\
\hline Sample period & 1973-2005 & 1973-2005 & $1973-2005$ & $1973-2005$ & 1989-2005 & 1989-2005 \\
\hline Observations & 677 & 677 & 847 & 847 & 461 & 461 \\
\hline
\end{tabular}

Note: All regressions are OLS and contain country fixed effects. Standard errors, which are shown in brackets, are clustered at the country-level. ${ }^{* * *}$ indicates significance at the $1 \%$ level, ${ }^{* *}$ at the $5 \%$ level and ${ }^{*}$ at the $10 \%$ level. Value added of finance is financial and insurance activities divided by GDP, intermediated credit is credit to the non-financial private sector by financial institutions divided by GDP, and stock market capitalisation is the value of all shares listed in a stock market divided by GDP. The sample covers $28-29$ OECD countries.

Source: OECD Secretariat calculations using OECD Structural Analysis database; World Bank Global Financial Development database; Bank for International Settlements credit series; Statistics Canada; A. Abiad, E. Detragiache and T. Tressel (2010), "A New Database of Financial Reforms", IMF Staff Papers, 75(2), pp. $281-302$. 
43. An alternative strategy, newly proposed in this paper, enables identifying the effect of financial deregulation on indicators of financial size after controlling for country-specific linear time trends and year fixed effects. It exploits the notion that deregulation can have different effects on finance depending on global economic conditions and on the extent of prior financial deregulation. Econometrically, this idea is implemented by interacting the financial deregulation variable with year fixed effects. Since this regression also serves in the next subsection as the first stage in the IV estimation, it involves the same explanatory variables as the growth specifications. The results in Table 12 reveal, on average across all years, a positive effect of financial deregulation on the value added of finance and intermediated credit (Columns 1 and 2). Financial deregulation has a negative effect on average stock market capitalisation (Column 5), which as discussed above is likely due to the dominance of the late 1990s bubble in the available sample. All three links are identified with a statistical confidence level of above $99.9 \%$.

44. The individual coefficients on the interaction terms between year fixed effects and financial deregulation (not shown) provide further insights. Financial deregulation has had a stronger impact on intermediated credit in recent years than thirty or fourty years ago. As the more recent part of the sample is characterised by a more relaxed stance of financial regulation, this suggests increasingly strong marginal effects of financial deregulation on credit size. As regards stock market capitalisation, the coefficients on the interactions, while on average negative, are positive during the stock market boom years of the late 1990s. This further highlights the strong influence of the dot-com boom-and-bust cycle on the estimated links between financial deregulation and stock market expansion.

45. Overall, these results support the view that financial deregulation has been a powerful driving force behind credit expansion and stock market bubble formation. However, at least two other explanations have been proposed, neither of which excludes the deregulation argument. Philippon and Reshef (2013) provide regression-based evidence that advances in information and communication technology have benefited finance more than other sectors. Gennaioli et al. (2014) argue that, since financial intermediaries are meant to help investors preserve their savings for future consumption, the increase in the capital share that has occurred in many OECD countries should have boosted the finance share in GDP. However, finance and the labour share exhibit no systematic correlation in the data used in this paper. ${ }^{7}$

7. The results for the three indicators of financial size are as follows: $i$ ) Regressing the value added of finance (\% of GDP) on the labour share (\%), plus country and year fixed effects, yields a coefficient of 0.027 and a p-value of 0.575 (clustering the standard errors by country). The number of observations is 712 and the Rsquared 0.880 . ii) Regressing intermediated credit (\% of GDP) on the labour share (\%), plus country and year fixed effects, yields a coefficient of 0.329 and a p-value of 0.571 (clustering the standard errors by country). The number of observations is 851 and the R-squared 0.853 . iii) Regressing stock market capitalisation (\% of GDP) on the labour share (\%), plus country and year fixed effects, yields a coefficient of -0.635 and a p-value of 0.606 (clustering the standard errors by country). The number of observations is 487 and the R-squared 0.822 . 
Table 12. The causal effect of finance on GDP growth per capita: The first stage

ECO/WKP(2015)41

\begin{tabular}{|c|c|c|c|c|c|c|c|}
\hline \multirow{2}{*}{$\begin{array}{l}\text { Dependent variable: } \\
\text { Sample: }\end{array}$} & \multirow{2}{*}{$\begin{array}{c}\text { Value added } \\
\text { of finance } \\
\text { OECD } \\
\text { (1) } \\
\end{array}$} & \multicolumn{3}{|c|}{ Intermediated credit } & \multicolumn{3}{|c|}{ Stock market capitalisation } \\
\hline & & $\begin{array}{c}\text { OECD } \\
(2) \\
\end{array}$ & $\begin{array}{c}\text { OECD \& G20 } \\
(3)\end{array}$ & $\begin{array}{c}\text { OECD } \\
(4) \\
\end{array}$ & $\begin{array}{c}\text { OECD } \\
(5) \\
\end{array}$ & $\begin{array}{c}\text { OECD \& G20 } \\
(6)\end{array}$ & $\begin{array}{c}\text { OECD } \\
(7) \\
\end{array}$ \\
\hline $\begin{array}{l}\text { F-statistics on financial deregulation } \\
\text { (interacted with year dummies) }\end{array}$ & 16.91 & 11.97 & 26.31 & 5.71 & 5.25 & 2.24 & 4.83 \\
\hline Investment rate & $\begin{array}{l}-0.023 \\
(0.020)\end{array}$ & $\begin{array}{c}0.367 \\
(0.518)\end{array}$ & $\begin{array}{c}0.292 \\
(0.441)\end{array}$ & $\begin{array}{c}0.658 \\
(0.595)\end{array}$ & $\begin{array}{l}1.851^{\star *} \\
(0.734)\end{array}$ & $\begin{array}{l}1.308 \\
(0.787)\end{array}$ & $\begin{array}{l}1.311^{*} \\
(0.707)\end{array}$ \\
\hline School years & $\begin{array}{l}-0.089 \\
(0.370)\end{array}$ & $\begin{array}{c}-15.331^{*} \\
(8.729)\end{array}$ & $\begin{array}{l}-8.952 \\
(7.211)\end{array}$ & $\begin{array}{c}-14.819^{*} \\
(7.989)\end{array}$ & $\begin{array}{c}5.643 \\
(18.245)\end{array}$ & $\begin{array}{c}12.607 \\
(12.404)\end{array}$ & $\begin{array}{c}4.880 \\
(17.855)\end{array}$ \\
\hline Population growth & $\begin{array}{c}0.013 \\
(0.112)\end{array}$ & $\begin{array}{c}1.828 \\
(2.021)\end{array}$ & $\begin{array}{c}2.306 \\
(2.200)\end{array}$ & $\begin{array}{c}1.748 \\
(2.001)\end{array}$ & $\begin{array}{c}0.611 \\
(3.192)\end{array}$ & $\begin{array}{l}-0.037 \\
(3.056)\end{array}$ & $\begin{array}{c}0.944 \\
(3.041)\end{array}$ \\
\hline Banking crisis dummy & - & - & - & $\begin{array}{c}10.643^{* * *} \\
(3.491)\end{array}$ & - & - & $\begin{array}{r}-10.402 \\
(6.533)\end{array}$ \\
\hline Year fixed effects & Yes & Yes & Yes & Yes & Yes & Yes & Yes \\
\hline R-squared & 0.914 & 0.954 & 0.956 & 0.957 & 0.912 & 0.915 & 0.914 \\
\hline Sample period & $1973-2005$ & 1973-2005 & $1973-2005$ & 1973-2005 & 1989-2005 & $1989-2005$ & $1989-2005$ \\
\hline Observations & 658 & 782 & 963 & 782 & 453 & 565 & 453 \\
\hline \multicolumn{8}{|c|}{ 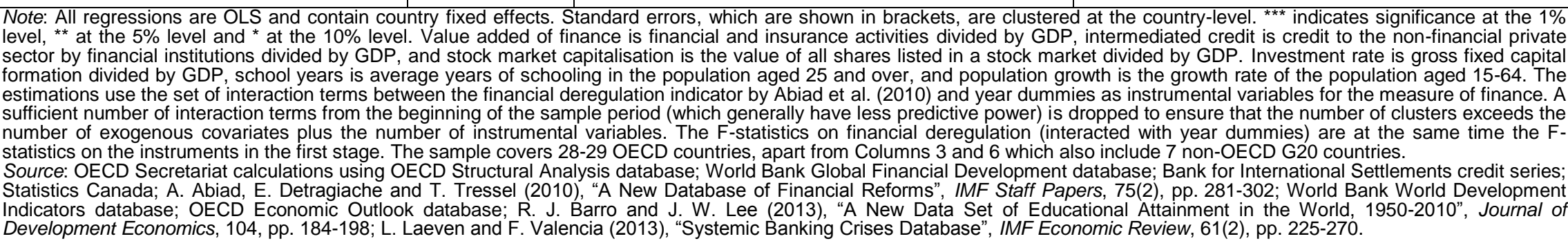 } \\
\hline
\end{tabular}




\subsection{Taking a new approach to evaluate the causal effect of finance on GDP growth}

46. The literature has been using two approaches to identify the causal impact of finance on growth (for an overview, see Beck, 2009). The first approach relies on IV specifications in cross-country and GMM methods in panel regressions. Levine et al. (2000) use legal origin as an instrument for private credit in cross-country regressions and past values of private credit as instruments for the current value of private credit in panel regressions. However, Bazzi and Clemens (2013) show that legal origin is not a valid instrument for private credit in growth regressions. Furthermore, past values of private credit represent very weak instruments, so that instrumenting with them can remove only a small fraction of the OLS bias. The second approach exploits variations across places or sectors within one country (e.g. Jayaratne and Strahan, 1996; Rajan and Zingales, 1998). However, by estimating the differential impact of finance on growth across certain places or sectors within a given country, this approach cannot shed much light on economy-wide effects.

47. This subsection proposes and employs an identification strategy that does not suffer from either of these shortcomings. Following the same approach as the previous subsection, differences in financial deregulation across countries and time serve as a source of exogenous variation in financial indicators. The paper uses these changes in policy as instruments for financial size in a novel way that allows keeping country-specific linear time trends in the regression to mitigate the risk of spurious results.

48. The idea is that deregulation influences finance, which in turn affects GDP growth. The econometric requirements are that the instruments be both strong and valid, namely that financial deregulation be highly correlated with financial size and have no link to or from GDP growth other than indirectly through financial size. Several checks point to the validity of the instruments:

1. Financial deregulation is indeed highly correlated with financial size, as the previous subsection showed.

2. There is little reason to believe that financial regulation could drive GDP growth other than through its effects on finance.

3. As a matter of thought, governments could respond to low or slowing growth by easing financial regulation. As a matter of fact, however, neither GDP growth nor its change significantly influences subsequent financial deregulation, as measured by Abiad et al.'s (2010) indicator. ${ }^{8}$

4. Also as a matter of thought, governments could respond to an economic downturn, especially when caused by financial factors, with more stringent financial regulation. Such behaviour would work in the direction of making tighter financial regulation correlated with weaker GDP growth, which is the opposite to what the present study finds. In any case, neither the size of the output gap nor the occurrence of a financial crisis predicts the tightness of the regulatory stance. ${ }^{9}$

49. The collinearity problem between financial deregulation and other trends is solved by interacting the financial deregulation indicator with year dummies and using the resulting set of year-specific financial deregulation variables as instruments for finance. This IV strategy can be interpreted in two ways. One is

8. Panel regressions incorporating country and year fixed effects indicate that neither GDP growth nor its difference compared with the previous year can explain subsequent changes in financial regulation. These regressions have been conducted on both the OECD and the full sample.

9. The precise results are as follows: $i)$ Regressing the financial deregulation indicator on the output gap (\% of GDP), plus country and year fixed effects, yields a coefficient of -0.002 and a p-value of 0.617 (clustering the standard errors by country). The number of observations is 738 and the R-squared 0.873 . ii) Regressing the financial deregulation indicator on the financial crisis indicator, plus country and year fixed effects, yields a coefficient of -0.035 and a p-value of 0.279 (clustering the standard errors by country). The number of observations is 921 and the R-squared 0.856 
that it allows the impact of financial deregulation on financial indicators to vary from year to year, which offers the advantage of reflecting the evolving effect of deregulation. The other is that individual economies were exposed to exogenous changes in the global macroeconomic environment, which influenced the worldwide growth of finance and are econometrically captured by the year fixed effects. Countries may, however, have reacted heterogeneously to a given global increase in finance, with those having less strict financial regulation responding more strongly, and this is precisely the variation that the interaction terms intend to exploit.

50. The instrumental variables regression results are reported in Tables 12 (for the first stage) and 13 (for the second stage). Standard errors are clustered at the country-level and corrected for the small sample size. As mentioned above, the first stage indicates that financial deregulation has a positive link with the value added of finance and intermediated credit but a negative one with stock markets. The first stage of the IV regression is statistically strong with the value added of finance and intermediated credit. In each case, the F-statistics on the instruments exceeds the critical value of 10 suggested by Angrist and Pischke (2009) and Stock et al. (2002). The first stage is relatively weaker for stock market capitalisation, which is consistent with the bubble in the available data disturbing the estimation.

51. The second-stage estimates indicate that causality runs from more intermediated credit to slower GDP growth and from greater stock market capitalisation to stronger GDP growth (Table 13). The OLS coefficient for the value added of finance switches signs and becomes insignificant in the instrumental variables specification (Column 1). By contrast, the IV estimates for intermediated credit and stock market capitalisation have the same sign as the OLS estimates and are statistically significant at the 5\% level, in the sample without (Columns 2 and 5) and with non-OECD G20 countries (Columns 3 and 6). The results for intermediated credit and stock market capitalisation are robust to the inclusion of the Laeven and Valencia (2013) financial crisis indicator (Columns 4 and 7). This last check means that causality goes beyond a story where financial deregulation slows economic growth due to more frequent financial crises. As further robustness checks, alternative regressions have been run by dropping countries one at a time. The significance of the IV estimates remains very similar, while their magnitude varies in a few cases.

52. In summary, when instrumenting with financial deregulation, the impact of intermediated credit on GDP growth remains strongly significant and negative and the impact of stock market capitalisation strongly significant and positive. On the other hand, the growth effect of financial sector value added stops being statistically significant. Put differently, the empirics indicate that excessive financial deregulation has contributed to the massive rise of intermediated credit and slower GDP growth.

\subsection{The standard GMM approach}

53. A more commonly used, although arguably less reliable, approach to determine causality from finance to growth is based on GMM. This requires the compression of the number of time periods in the present setup (51 years) and is therefore conducted in the sample with 5-year averages. The most popular GMM estimator deployed in panel data growth econometrics is Blundell and Bond's (1998) system GMM. The number of lagged levels in the instrument matrix for the difference equation is restricted to one, and the instrument matrix is "collapsed" so that it includes one instrument per explanatory variable instead of one instrument per period and explanatory variable. This is done to mitigate the problem of instrument proliferation (Roodman, 2009).

54. The results are reported in Table 6 (Columns 2, 4 and 6). Standard errors are robust using Windmeijer's (2005) finite-sample correction. The coefficient on the value added of finance, already statistically insignificant in the OLS regression, remains insignificant. The estimate on intermediated credit is negative and significant at the $10 \%$ level. Stock market capitalisation is positively linked with growth but in a statistically insignificant fashion, which is probably related to the reduction in the number of time periods in the GMM to just three. The instruments pass the Hansen test of validity in all three cases. 
Table 13. The causal effect of finance on GDP growth per capita: The second stage

\begin{tabular}{|c|c|c|c|c|c|c|c|}
\hline \multirow{3}{*}{$\begin{array}{l}\text { Dependent variable: } \\
\text { Measure of finance: } \\
\text { Sample: }\end{array}$} & \multicolumn{7}{|c|}{ GDP growth per capita } \\
\hline & \multirow{2}{*}{$\begin{array}{c}\begin{array}{c}\text { Value added } \\
\text { of finance }\end{array} \\
\text { OECD } \\
\text { (1) }\end{array}$} & \multicolumn{3}{|c|}{ Intermediated credit } & \multicolumn{3}{|c|}{ Stock market capitalisation } \\
\hline & & $\begin{array}{l}\text { OECD } \\
(2)\end{array}$ & $\begin{array}{c}\text { OECD \& G20 } \\
\text { (3) }\end{array}$ & $\begin{array}{l}\text { OECD } \\
\text { (4) }\end{array}$ & $\begin{array}{l}\text { OECD } \\
\text { (5) }\end{array}$ & $\begin{array}{c}\text { OECD \& G20 } \\
(6)\end{array}$ & $\begin{array}{l}\text { OECD } \\
(7)\end{array}$ \\
\hline Measure of finance & $\begin{array}{c}0.721 \\
(0.721)\end{array}$ & $\begin{array}{c}-0.126^{\star \star *} \\
(0.037)\end{array}$ & $\begin{array}{c}-0.095^{\star *} \\
(0.037)\end{array}$ & $\begin{array}{c}-0.112^{* *} \\
(0.045)\end{array}$ & $\begin{array}{c}0.105^{\star \star \star} \\
(0.034)\end{array}$ & $\begin{array}{l}0.086^{* *} \\
(0.035)\end{array}$ & $\begin{array}{l}0.098^{\star \star \star} \\
(0.031)\end{array}$ \\
\hline Investment rate & $\begin{array}{l}0.117^{* *} \\
(0.043)\end{array}$ & $\begin{array}{l}0.243^{* *} \\
(0.091)\end{array}$ & $\begin{array}{c}0.275^{\star * *} \\
(0.070)\end{array}$ & $\begin{array}{l}0.227^{* *} \\
(0.099)\end{array}$ & $\begin{array}{c}0.118 \\
(0.101)\end{array}$ & $\begin{array}{c}0.221 \\
(0.193)\end{array}$ & $\begin{array}{c}0.067 \\
(0.095)\end{array}$ \\
\hline School years & $\begin{array}{l}1.805^{\star} \\
(0.934)\end{array}$ & $\begin{array}{l}-0.386 \\
(0.949)\end{array}$ & $\begin{array}{c}0.448 \\
(0.703)\end{array}$ & $\begin{array}{l}-0.211 \\
(0.925)\end{array}$ & $\begin{array}{c}0.509 \\
(1.581)\end{array}$ & $\begin{array}{c}0.285 \\
(1.751)\end{array}$ & $\begin{array}{c}0.290 \\
(1.373)\end{array}$ \\
\hline Population growth & $\begin{array}{l}-0.582^{\star *} \\
(0.228)\end{array}$ & $\begin{array}{c}-0.484^{* *} \\
(0.235)\end{array}$ & $\begin{array}{c}-0.573^{* *} \\
(0.245)\end{array}$ & $\begin{array}{l}-0.493^{*} \\
(0.249)\end{array}$ & $\begin{array}{l}-0.512 \\
(0.700)\end{array}$ & $\begin{array}{l}-0.470 \\
(0.593)\end{array}$ & $\begin{array}{l}-0.447 \\
(0.700)\end{array}$ \\
\hline Banking crisis dummy & - & - & - & $\begin{array}{l}-0.594 \\
(0.968)\end{array}$ & - & - & $\begin{array}{l}-1.410 \\
(0.928)\end{array}$ \\
\hline Year fixed effects & Yes & Yes & Yes & Yes & Yes & Yes & Yes \\
\hline Sample period & $1973-2005$ & 1973-2005 & 1973-2005 & 1973-2005 & $1989-2005$ & $1989-2005$ & 1989-2005 \\
\hline Observations & 658 & 782 & 963 & 782 & 453 & 565 & 453 \\
\hline
\end{tabular}

Note: All regressions are IV and contain country fixed effects. Standard errors, which are shown in brackets, are clustered at the country-level and corrected for the small sample size. ${ }^{* \star *}$ indicates significance at the $1 \%$ level, ${ }^{* \star}$ at the $5 \%$ level and ${ }^{*}$ at the $10 \%$ level. Value added of finance is financial and insurance activities divided by GDP, intermediated credit is credit to the non-financial private sector by financial institutions divided by GDP, and stock market capitalisation is the value of all shares listed in a stock market divided by GDP. Investment rate is gross fixed capital formation divided by GDP, school years is average years of schooling in the population aged 25 and over, and population growth is the growth rate of the population aged 15-64. The estimations use the set of interaction terms between the financial deregulation indicator by Abiad et al. (2010) and year dummies as instrumental variables for the measure of finance. A sufficient number of interaction terms from the beginning of the sample period (which generally have less predictive power) is dropped to ensure that the number of clusters exceeds the number of instrumental variables plus the number of exogenous covariates (with the country fixed effects, year fixed effects and country-specific linear time trends partialled out). The sample covers 28-29 OECD countries, apart from Columns 3 and 6 which also include 7 non-OECD G20 countries.

Source: OECD Secretariat calculations using OECD Structural Analysis database; World Bank Global Financial Development database; Bank for International Settlements credit series; Statistics Canada; A. Abiad, E. Detragiache and T. Tressel (2010), "A New Database of Financial Reforms", IMF Staff Papers, 75(2), pp. 281-302. World Bank World Development Indicators database; OECD Economic Outlook database; R. J. Barro and J. W. Lee (2013), "A New Data Set of Educational Attainment in the World, 1950-2010", Journal of Development Economics, 104, pp. 184-198; L. Laeven and F. Valencia (2013), "Systemic Banking Crises Database", IMF Economic Review, 61(2), pp. 225-270. 


\section{The structure of finance}

55. The previous section characterised excessive financial deregulation as one transmission channel behind the link from higher intermediated credit to slower economic growth. Additional mechanisms are likely related to the quality and structure of finance, and they are explored next. This section examines the possible growth consequences of, in sequential order, the overall composition of finance, the composition of financial sector value added and the composition of intermediated credit. The last two subsections look at the role of external markets and implicit guarantees for bank debt.

\subsection{The overall composition of finance}

56. To investigate the relationship between the overall composition of finance and GDP growth, the three measures of finance are simultaneously included in the baseline specification with country-specific linear time trends (Table 14). Intermediated credit is negatively and stock market capitalisation positively related with GDP growth. The two coefficients are estimated with high precision, whereas the one on the value added of finance, although negative, is statistically insignificant at conventional levels (Column 1). The twin findings of a negative link between debt finance and GDP growth and of a positive link between equity finance and GDP growth imply that shifting finance from debt to equity, while holding its overall amount constant, would raise GDP growth.

\subsection{The composition of the value added of finance}

57. In an additional analysis of the financial structure, the value added of finance (comprising finance and insurance and pension funding) is decomposed into: $i$ ) banking, $i i$ ) insurance and pension funding and iii) auxiliary financial activities (Table 14). The value added of banking comprises the financial service activities of banks, holding companies, trusts, funds and similar financial entities. The value added of insurance and pension funding comprises the activities of life insurance, non-life insurance, reinsurance and pension funds. The value added of auxiliary financial activities comprises the administration of financial markets, security and commodity contracts brokerage, risk and damage evaluation, and activities of insurance agents, brokers and fund managers. Banks and other lenders make by far the largest contribution to the financial sector, accounting for two-thirds of its value added on average. Nevertheless, the three components of financial sector value added have expanded at broadly similar rates in most OECD countries.

58. Including these components individually in the baseline specification yields negative coefficients for banking as well as insurance and pension funding and a positive coefficient for auxiliary financial activities (Column 2). The results suggest that banks and insurance companies stand behind the negative link between financial sector value added and growth. Although insurance has a more negative coefficient than banking, banking contributes strongly to the negative link between overall financial sector value added and growth given its large value added. The empirical results in the two columns are broadly in line. Credit by banks and other financial institutions is an important source of the value added by banks, insurers and pension funds. By contrast, stock market capitalisation is arguably most closely associated with the value added of auxiliary financial activities. 
ECO/WKP(2015)41

Table 14. The relationship between the structure of finance and GDP growth per capita

\begin{tabular}{|c|c|c|c|}
\hline Dependent variable: & $\begin{array}{c}\text { GDP growth per capita } \\
(1)\end{array}$ & Dependent variable: & $\begin{array}{c}\text { GDP growth per capita } \\
(2)\end{array}$ \\
\hline Value added of finance & $\begin{array}{l}-0.142 \\
(0.140)\end{array}$ & Value added of banking & $\begin{array}{l}-0.219 \\
(0.136)\end{array}$ \\
\hline Intermediated credit & $\begin{array}{c}-0.033^{* * *} \\
(0.010)\end{array}$ & $\begin{array}{l}\text { Value added of } \\
\text { insurance and pensions }\end{array}$ & $\begin{array}{l}-0.528 \\
(0.363)\end{array}$ \\
\hline Stock market capitalisation & $\begin{array}{l}0.022^{\star * *} \\
(0.006)\end{array}$ & $\begin{array}{l}\text { Value added of auxiliary } \\
\text { finance }\end{array}$ & $\begin{array}{l}0.966^{\star} \\
(0.532)\end{array}$ \\
\hline Investment rate & $\begin{array}{l}0.299 * * * \\
(0.077)\end{array}$ & Investment rate & $\begin{array}{l}0.247^{* * *} \\
(0.062)\end{array}$ \\
\hline School years & $\begin{array}{c}0.368 \\
(1.008)\end{array}$ & School years & $\begin{array}{l}1.826^{\star *} \\
(0.849)\end{array}$ \\
\hline Population growth & $\begin{array}{l}-0.560 \\
(0.377)\end{array}$ & Population growth & $\begin{array}{l}-0.527^{\star} \\
(0.282)\end{array}$ \\
\hline Year fixed effects & Yes & Year fixed effects & Yes \\
\hline Linear country trends & Yes & Linear country trends & Yes \\
\hline R-squared & 0.663 & R-squared & 0.664 \\
\hline Sample period & $1989-2011$ & Sample period & $1970-2011$ \\
\hline Observations & 620 & Observations & 592 \\
\hline
\end{tabular}

Note: All regressions are OLS and contain country fixed effects. Standard errors, which are shown in brackets, are clustered at the country-level. ${ }^{* * *}$ indicates significance at the $1 \%$ level, ${ }^{* *}$ at the $5 \%$ level and ${ }^{*}$ at the $10 \%$ level. On the left-hand side, value added of finance is financial and insurance activities divided by GDP, intermediated credit is credit to the non-financial private sector by financial institutions divided by GDP, and stock market capitalisation is the value of all shares listed in a stock market divided by GDP. On the right-hand side, value added of banking is financial activities, except insurance and pension funding, divided by GDP: This item comprises the financial activities of banks, holding companies, trusts, funds and similar financial entities. Value added of insurance and pensions is insurance and pension funding, except compulsory social security, divided by GDP: This item comprises the activities of life insurance, non-life insurance, reinsurance and pension funds. Value added of auxiliary finance is auxiliary financial activities divided by GDP: This item comprises the administration of financial markets, security and commodity contracts brokerage, risk and damage evaluation, and activities of insurance agents, brokers and fund managers. Investment rate is gross fixed capital formation divided by GDP, school years is average years of schooling in the population aged 25 and over, and population growth is the growth rate of the population aged 15-64. The sample covers 32 (Column 1) and 26 (Column 2) OECD countries.

Source: OECD Secretariat calculations using OECD Structural Analysis database; World Bank Global Financial Development database; Bank for International Settlements credit series; Statistics Canada; World Bank World Development Indicators database; OECD Economic Outlook database; R. J. Barro and J. W. Lee (2013), "A New Data Set of Educational Attainment in the World, 19502010", Journal of Development Economics, 104, pp. 184-198.

\subsection{The composition of private credit}

59. To study the role of the composition of private credit for economic growth, this subsection first examines the influence of the quality of credit. It then decomposes the empirical links in the credit-growth nexus along two dimensions: by type of borrower (households versus corporations) and by type of lender (banks versus non-banks). 
ECO/WKP(2015)41

\section{The quality of credit}

60. Besides the quantity of credit, its quality also matters for GDP growth. Approximating lowquality credit by the share of non-performing loans in total loans does not materially affect the estimated relationship between intermediated credit and GDP growth (Table 15), neither in the sample of only OECD (Column 1) nor in the broader one that also includes the non-OECD G20 countries (Column 2). This result suggests a negative influence of high levels of intermediated credit on GDP growth beyond the lower average quality that they may entail. The quality of lending is positively related with growth, although this conclusion comes with the caveat that it might stem from slower growth resulting in a higher default rate on loans.

\section{Household credit versus corporate credit}

61. Housing finance can influence economic growth through various channels. For instance, an overextension of housing finance, which can stem from significant tax advantages (Cournède et al., 2015), may misallocate capital and thereby slow GDP growth. Furthermore, housing construction notoriously generates boom-and-bust cycles (Angeles, 2015). This paper uses household credit as a proxy for the amount of housing finance. Although this represents a shortcut, households usually borrow much lower amounts for other uses, such as education, cars or other purchases. In the United States for example, threequarters of total household credit finances house purchases (Federal Reserve Bank of New York, 2013). Another source of measurement imperfection is that household credit does not include loans to developers and builders, which fall within the purview of credit to the non-financial business sector.

62. In the data, total credit to the non-financial private sector in the form of loans, bonds and shortterm paper comprises two components: credit to households (including non-profit institutions serving households) and credit to non-financial corporations. Lenders are deposit money banks and other financial institutions, non-financial corporations, central banks, general government, households and non-profit institutions serving households. The proportion of household in total credit varies among OECD countries from $15 \%$ in Luxembourg to $61 \%$ in Australia. When the baseline specification separates credit between households and corporations (Table 15), the coefficient on household credit is, in absolute value, about twice as large as the one on corporate credit. This is the case without (Column 3) and with non-OECD G20 countries (Column 4).

63. Although the household and corporate coefficients are not significantly different from each other, the magnitude of the difference nonetheless suggests that housing-related credit excesses are a particularly harmful source of financial overextension. In addition, the data indicate that more intermediated credit is associated with a higher share of household credit in total credit, although not in a statistically significant fashion. ${ }^{10}$ Hence, the tight link between lower growth and higher household credit suggests that the structural change in the composition of credit towards household credit has been another factor behind the negative association of higher credit with GDP growth. Historically, the variation in corporate credit has been approximately twice that in household credit, implying that a typical change for either type of credit has about the same association with GDP growth.

10. Regressing the share of household credit in total credit $(\%)$ on intermediated credit (\% of GDP), plus country and year fixed effects, yields a coefficient of 0.035 and a p-value of 0.266 (clustering the standard errors by country). The number of observations is 739 and the R-squared 0.849 . 
Table 15. The relationship between the structure of credit and GDP growth per capita

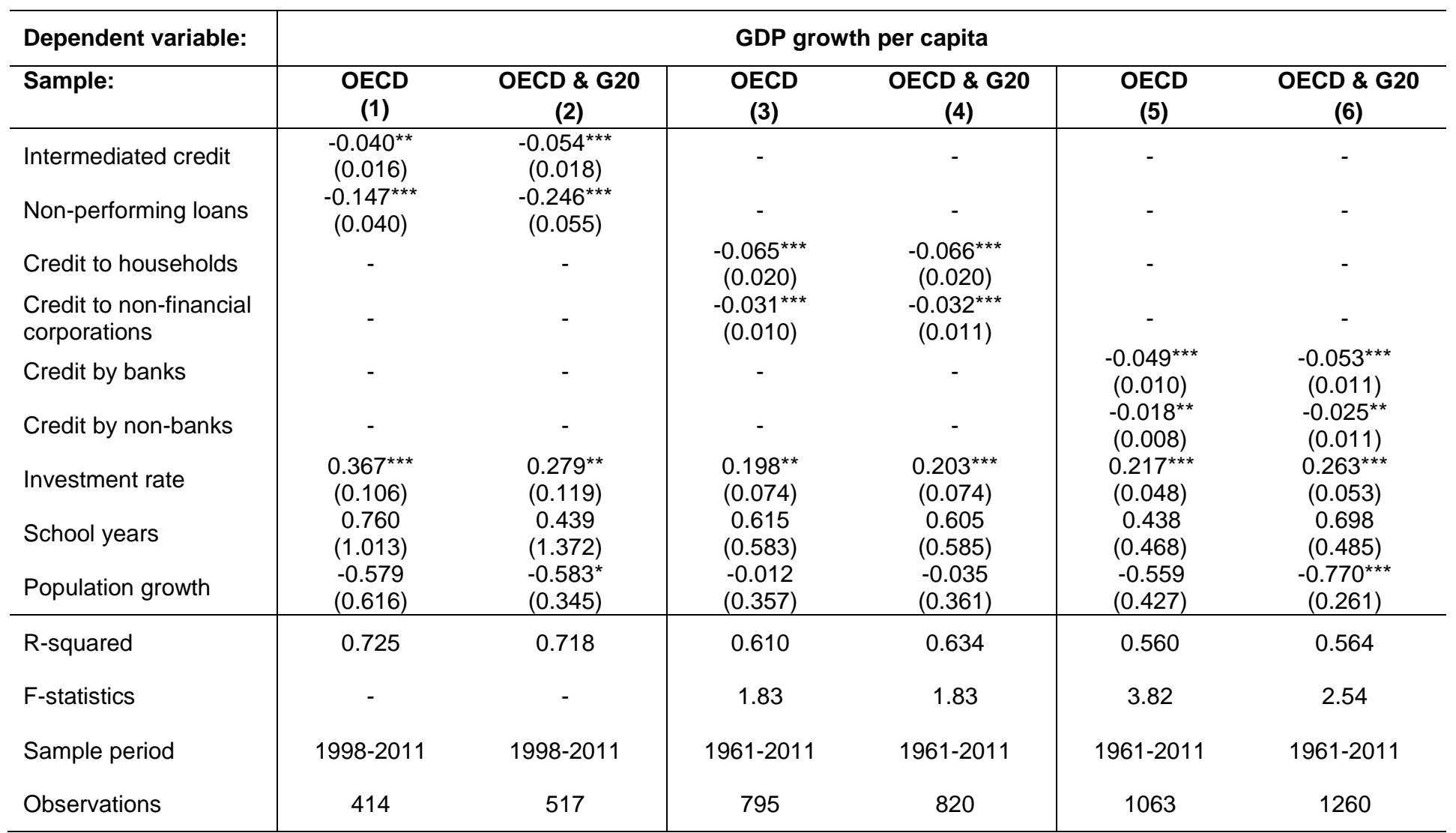

Note: All regressions contain country fixed effects, year fixed effects and country-specific linear time trends. Standard errors, which are shown in brackets, are clustered at the countrylevel. ${ }^{* * *}$ indicates significance at the $1 \%$ level, ${ }^{* *}$ at the $5 \%$ level, and ${ }^{*}$ at the $10 \%$ level. Intermediated credit is credit to the non-financial private sector by financial institutions divided by GDP, and non-performing loans is the ratio of defaulting loans to total gross loans for banks. Credit to households and credit to non-financial corporations are, respectively, credit by by GDP, and deposit mentions to households and non-profit institutions serving households and to non-financial corporations divided by GDP. Credit by banks and credit by non-banks are, respectively, credit by deposit money banks and by non-financial corporations, central banks, financial institutions other than deposit money banks, general government, households and non-profit institutions serving households divided by GDP. Investment rate is gross fixed capital formation divided by GDP, school years is average years of schooling in the population aged 25 and over, and population growth is the growth rate of the population aged 15-64. The F-statistics test the equality of the coefficients for the types of credit.

Source: OECD Secretariat calculations using Bank for International Settlements credit series; World Bank World Development Indicators database; OECD Economic Outlook database; R. J. Barro and J. W. Lee (2013), "A New Data Set of Educational Attainment in the World, 1950-2010", Journal of Development Economics, 104, pp. 184-198. 
ECO/WKP(2015)41

\section{Bank credit versus non-bank credit}

64. Investment by the non-financial sector, especially larger corporations, often uses bonds, shares and other financial market instruments, which are largely held by market participants other than financial intermediaries. The literature has suggested several theoretical arguments why bank and market finance may have different effects on economic performance. For example, since investors can usually sell their shares and bonds in liquid markets, market finance could provide fewer incentives for shareholders and bondholders than banks to monitor managers (Bhide, 1993; Diamond, 1984). On the other hand, powerful banks may stymie innovation by extracting informational rents and protecting established firms with which they have close links from competition (Hellwig, 1991; Rajan, 1992).

65. Most empirical studies from the period before the financial crisis have not supported either view. Levine (2002) finds no significant difference in country-level data between the effect of bank and market finance on economic growth. Beck and Levine (2002) argue that growth rates of industries requiring more external finance are no different between bank- and market-based economies. Demirgüç-Kunt and Maksimovic (2002) trace no evidence in firm-level data for 40 countries that the access of firms to external finance would be associated with a stronger development of stock markets relative to banks. In these papers, the overall level of financial development, rather than its structure, explains differences in economic outcomes. ${ }^{11}$

66. Supplementing the empirical analysis in Section 2 with a measure of non-bank credit suggests that bank credit is associated with comparatively poorer economic performance. The data distinguish two measures of credit to the non-financial private sector (which includes loans, bonds and short-term paper): credit provided by deposit money banks and credit provided by other lenders, including financial institutions other than deposit money banks, the central bank, the general government, non-financial corporations, households and non-profit institutions serving households. The share of bank in total credit tends to be higher in emerging market economies and exhibits a wide dispersion among OECD and G20 countries, from 23\% in Belgium to $96 \%$ in South Africa. Although these data do not allow separating loans from bonds and short-term paper, loans are likely to make up a much larger share in bank than non-bank credit. When bank and non-bank credit, relative to GDP, are jointly included as explanatory variables in the baseline specification, both are negative and statistically significant (Table 15). The coefficient on bank credit is substantially larger in absolute value. For OECD countries, the two estimates are statistically different at the 10\% level (Column 5); however, they are not when non-OECD G20 countries are added (Column 6). These results are robust to excluding the United States, a country with a high share of capitalmarket credit, from the sample.

67. The particularly tight negative links of credit to households and credit by banks with GDP growth suggest that shifting the composition of finance to other types of credit could promote growth. This view is in line with other recent empirical evidence showing that market-based financial systems are more conducive to growth and innovation than bank-based ones (European Systemic Risk Board, 2014; Gambacorta et al., 2014; Hsu et al., 2014; Langfield and Pagano, 2015). The data also indicate that more intermediated credit is associated with a higher share of bank in total credit, although not in a statistically significant fashion. ${ }^{12}$ Hence, the more negative relationship of bank, relative to non-bank, credit with growth suggests that the trend in the composition of credit towards bank credit has been another factor behind the increasingly more negative association between higher credit and GDP growth. Historically, the

11. A separate line of research has compared the implications of debt and equity for financial and macroeconomic stability (see for instance Schularick and Taylor, 2012, and Sutherland et al., 2012).

12. Regressing the share of bank credit in total credit (\%) on intermediated credit (\% of GDP), plus country and year fixed effects, yields a coefficient of 0.050 and a p-value of 0.308 (clustering the standard errors by country). The number of observations is 993 and the R-squared 0.820 . 
variations in bank credit and non-bank credit have been about the same, implying that a typical change in credit has a more negative relationship with GDP growth for bank credit.

\subsection{External trade}

68. In today's world of global value chains, the role of the financial sector for economic performance could depend on whether financial services are produced for domestic or external consumption. Domestic production and consumption of finance may differ significantly, especially in countries hosting international financial centres or exporting a lot of financial services. The empirical analysis in Section 2 indicates that above-trend private sector indebtedness generally slows GDP growth. This observation would suggest that the negative finance-growth link might stem more from the consumption rather than the production of financial services. It may thus be conjectured that the size of the financial sector could exhibit a lower correlation with GDP growth when more financial activities are exported and fewer imported. Past OECD work investigated a related but distinct question by examining the relationship between international financial integration and the vulnerability to financial crises (Ahrend et al., 2012).

69. To explore these issues, the domestic consumption of financial services is calculated as a proportion of their value added contribution to GDP (Figure 11). Domestic consumption is obtained by subtracting exports and adding imports of financial activities. ${ }^{13}$ A value of $100 \%$ means that domestic consumption of financial services equals their domestic production, or that net exports are zero. While most OECD countries consume financial services near the amount they produce, some exceptions stand out. A striking one is Luxembourg, which in 2009 produced 25 times as much in financial services as it consumed. Other large exporting countries are Switzerland, Iceland and Austria. By contrast, some OECD countries, including those in Eastern Europe, import a relatively large share of the financial services that they use.

13. Given the available data, domestic consumption is calculated by subtracting exports to other OECD countries and adding imports from other OECD countries, not the rest of the world. 
Figure 11. Ratio of domestic consumption to domestic production of financial activities In percentage

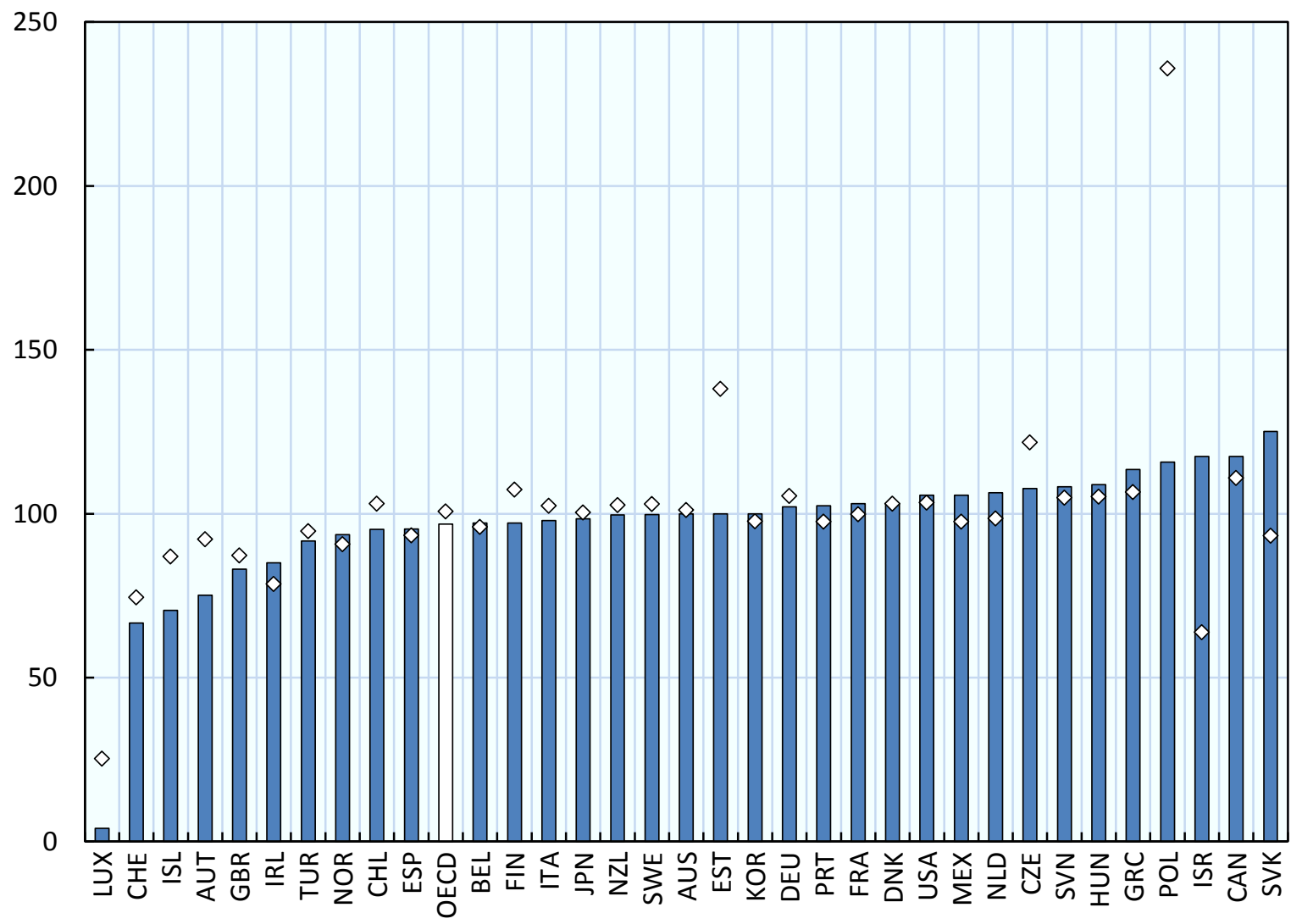

Note: Domestic consumption equals domestic production (or the value added of finance) minus exports plus imports of financial activities (in value added terms), to and from other OECD countries respectively. OECD is the simple average of OECD countries.

Source: OECD Structural Analysis database; OECD Trade in Value Added database; OECD Secretariat calculations.

70. Extensions of the regression framework in Section 2 provide evidence that the link between the value added of finance and GDP growth is more negative for domestic consumption than production. In a first approach, a dummy variable for not being a financial centre is constructed equalling 1 in all OECD countries except the five largest net exporters of financial services between 1995 and 2009 (Austria, Iceland, Ireland, Luxembourg and Switzerland), where it is set to zero. The negative bivariate relationship between the value added of finance and GDP growth is somewhat weaker for the five countries classified as financial centres than the other ones (Figure 12). Adding the same controls as in the baseline specification (Table 16) shows that the link between finance and growth is almost twice as strong and continues to be significant when the five financial centre countries are excluded from the sample (Column 1). When financial size is included in the regression both alone and interacted with the dummy for not being a financial centre, the interaction term appears to reinforce the financial size effect (Column 2). However, the difference between OECD countries classified as financial centres and the other ones is not statistically significant. 
Figure 12. The role of trade in financial services for the bivariate relationship between the value added of finance and GDP growth per capita

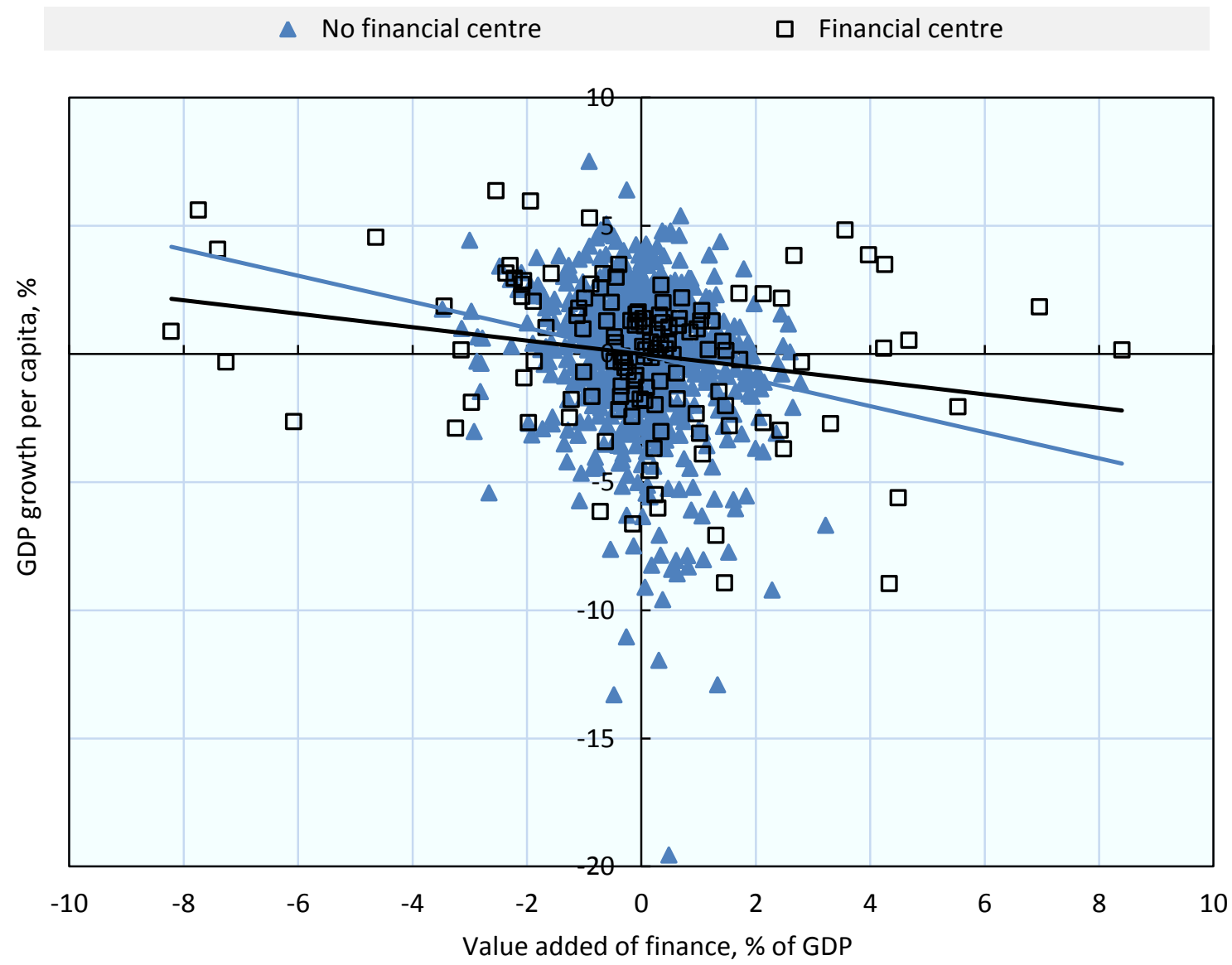

Note: The sample covers 32 OECD countries between 1970 and 2011. Points labelled "Financial centre" are observations from Austria, Iceland, Ireland, Luxembourg and Switzerland, the five OECD countries with the lowest ratio of domestic consumption to domestic production of financial and insurance activities on average during 1995-2009. The lines indicate the fitted values of an OLS regression through the data points. The two variables are demeaned using the respective country means to average out differences between countries that are persistent over time.

Source: OECD Structural Analysis database; OECD Trade in Value Added database; World Bank World Development Indicators database; OECD Secretariat calculations.

71. The results are broadly the same when financial size is interacted with the ratio of domestic consumption to production. In this second approach, each observation for the value added of finance is multiplied by the consumption-to-production ratio averaged for each country over 1995, 2000, 2005 and 2009 , the years for which data were available at the time of writing. This way, net exports of financial services are approximated to be a time-invariant fraction of their domestic production. The OLS estimate rises when applying this proxy for domestic consumption (Column 3) compared with domestic production. Domestic consumption appears to be more important than domestic production when both are included in the regression, although due to their high correlation neither is statistically significant (Column 4). 
ECO/WKP(2015)41

Table 16. The role of trade in financial services for the relationship between the value added of finance and GDP growth per capita

\begin{tabular}{|c|c|c|c|c|}
\hline \multirow[t]{2}{*}{ Dependent variable: } & \multicolumn{4}{|c|}{ GDP growth per capita } \\
\hline & (1) & (2) & (3) & (4) \\
\hline Value added of finance & - & $\begin{array}{l}-0.104^{* *} \\
(0.051)\end{array}$ & - & $\begin{array}{l}-0.046 \\
(0.089)\end{array}$ \\
\hline $\begin{array}{l}\text { Value added of finance } \\
\text { interacted with no finance centre }\end{array}$ & $\begin{array}{l}-0.506^{\star *} \\
(0.243)\end{array}$ & $\begin{array}{l}-0.363 \\
(0.253)\end{array}$ & - & - \\
\hline $\begin{array}{l}\text { Value added of finance } \\
\text { interacted with domestic share }\end{array}$ & - & - & $\begin{array}{l}-0.403^{*} \\
(0.199)\end{array}$ & $\begin{array}{l}-0.351 \\
(0.271)\end{array}$ \\
\hline Investment rate & $\begin{array}{l}0.176^{* * *} \\
(0.051)\end{array}$ & $\begin{array}{l}0.188^{* * *} \\
(0.045)\end{array}$ & $\begin{array}{l}0.194^{* * *} \\
(0.047)\end{array}$ & $\begin{array}{l}0.193^{\star \star *} \\
(0.048)\end{array}$ \\
\hline School years & $\begin{array}{l}1.600^{*} \\
(0.795)\end{array}$ & $\begin{array}{l}1.456^{*} \\
(0.798)\end{array}$ & $\begin{array}{l}1.427^{*} \\
(0.804)\end{array}$ & $\begin{array}{l}1.430^{*} \\
(0.806)\end{array}$ \\
\hline Population growth & $\begin{array}{l}-0.201 \\
(0.282)\end{array}$ & $\begin{array}{l}-0.192 \\
(0.225)\end{array}$ & $\begin{array}{l}-0.184 \\
(0.227)\end{array}$ & $\begin{array}{l}-0.185 \\
(0.227)\end{array}$ \\
\hline Year fixed effects & Yes & Yes & Yes & Yes \\
\hline Linear country trends & Yes & Yes & Yes & Yes \\
\hline R-squared & 0.593 & 0.594 & 0.593 & 0.593 \\
\hline Sample period & $1970-2011$ & $1970-2011$ & $1970-2011$ & $1970-2011$ \\
\hline Observations & 814 & 948 & 948 & 948 \\
\hline
\end{tabular}

Note: All regressions are OLS and contain country fixed effects. Standard errors, which are shown in brackets, are clustered at the country-level. ${ }^{* * *}$ indicates significance at the $1 \%$ level, ${ }^{* *}$ at the $5 \%$ level, and ${ }^{*}$ at the $10 \%$ level. Value added of finance is financial and insurance activities divided by GDP, no financial centre is a dummy variable that takes the value of 0 for Austria, Iceland, Ireland, Luxembourg and Switzerland and 1 otherwise, and domestic share is domestic consumption of financial services (measured in value added) divided by the value added of finance (averaged over 1995, 2000, 2005 and 2009). Investment rate is gross fixed capital formation divided by GDP, school years is average years of schooling in the population aged 25 and over, and population growth is the growth rate of the population aged 15-64. The sample covers 27 (Column 1) and 32 (Columns 2-4) OECD countries.

Source: OECD Secretariat calculations using OECD Structural Analysis database; OECD Trade in Value Added database; World Bank World Development Indicators database; OECD Economic Outlook database; R. J. Barro and J. W. Lee (2013), "A New Data Set of Educational Attainment in the World, 1950-2010", Journal of Development Economics, 104, pp. 184-198.

\subsection{The competitive structure of the financial industry}

72. The competitive structure of the financial industry may influence the sign and magnitude of its links with economic growth. A growing literature documents the large implicit public subsidies that financial institutions receive (Admati and Hellwig, 2013; Schich et al., 2014; Schich and Lindh, 2012; Ueda and Weder di Mauro, 2013). Denk et al. (2015) provide evidence in support of this view, using the baseline estimation approach in this paper. They show that the link between bank credit and growth is more negative in countries where implicit bank debt guarantees are estimated to be larger. They also find that bank credit is more tightly associated with slower growth in those OECD countries where senior creditors did not incur losses on bank debt due to bank failures than in those ones where they participated in the burden sharing.

73. These results point to large benefits of reducing implicit public subsidies to too-big-to-fail banks. This could be achieved through reducing concentration of the banking sector, which may involve breakups, and by more generally raising competition among banks. An alternative to breaking up banks to make 
them "small-enough-to-fail" is to impose capital surcharges that internalise the too-big-to-fail subsidy. Schich et al. (2014) estimate that public backing reduced the funding costs of a sample of large European banks by 1.3 percentage points in 2013. A rough calculation using the funding cost difference between equity and other liabilities suggests that a capital surcharge of about $13 \%$ of unweighted assets would be needed to offset the funding advantage generated by public backing (Appendix 2). In practice, the capital surcharges implemented by Basel III (Basel Committee on Banking Supervision, 2011) seem unlikely to induce too-big-to-fail banks to fully internalise the negative externalities they may exert on financial stability. As of end-2013, the Financial Stability Board identified no bank as requiring a capital surcharge of $3 \frac{1}{2}$ per cent of risk-weighted assets while only two were classified in the bucket where a $2^{1 / 2}$ per cent surcharge applies.

74. These findings are in line with the evidence in Subsection 6.3 that credit by banks, which tend to benefit more from too-big-to-fail guarantees than other financial institutions, is more negatively related with economic growth than capital-market credit. Other indirect evidence suggests the sharing of economic rents from implicit guarantees between bank debtors and financial sector employees. If implicit guarantees were in part channelled to the banks' debtors and employees, one would expect a positive correlation between intermediated credit and financial sector wage premia. Wage premia are what financial institutions pay their employees in excess of the remuneration of employees in other sectors with similar observable characteristics (such as age, education, gender or experience). The empirical analysis indicates that this is indeed the case: The size of credit is positively linked with higher wage premia. ${ }^{14}$

14. Regressing intermediated credit (\% of GDP) on the financial sector wage premium (\%), plus country and year fixed effects, yields a coefficient of 0.272 and a p-value of 0.003 (clustering the standard errors by country). The number of observations is 461 and the R-squared 0.891. The sample covers OECD countries between 1970 and 2005. The estimates for the financial sector wage premia in this exercise are taken from Denk (2015). 
ECO/WKP(2015)41

\section{APPENDIX 1. DATA SOURCES}

75. The main data sources used in this paper are: OECD Structural Analysis (STAN) database and OECD Secretariat calculations for the value added of finance; World Bank Global Financial Development database for intermediated credit and stock market capitalisation; World Bank World Development Indicators database for GDP growth per capita, the investment rate in non-OECD G20 countries and population growth; OECD Economic Outlook database for the investment rate in OECD countries; and Barro and Lee (2013) for average years of schooling.

76. The value added of finance is based on industry codes 64-66 following ISIC Rev. 4 classification and therefore includes financial service activities of banks, insurance, pension funds and other financial intermediaries. Insofar as financial activities traditionally associated with banks have over time migrated to other financial corporations, they continue to be accounted for. Intermediated credit is defined as credit to the non-financial private sector by deposit money banks and other financial institutions. Missing values (14 in total) for intermediated credit between years with data have been interpolated.

77. Intermediated credit from the World Bank Global Financial Development database exhibits apparent breaks for Canada and Denmark. The data for Denmark are replaced by the credit series from the Bank for International Settlements (BIS). The difference in their definition is that the data from the World Bank refer to deposit money banks and other financial institutions (Čihák et al., 2012) and the data from the BIS to deposit money banks only (Dembiermont et al., 2013). Data published by Statistics Canada have been used for this country. The BIS series was not used for Canada because it does not include credit provided by other financial institutions, which makes up a substantial proportion of overall intermediated credit in Canada. The choice of the data source does not materially affect the results.

78. The robustness checks in Section 3 make use of the following additional data sources: Laeven and Valencia (2013) for the financial crisis indicator; OECD Economic Outlook database for private consumption, government consumption, trade openness, the growth of potential GDP per capita and the share of housing investment in total investment; OECD Patent database for patent applications; OECD Analytical Business Enterprise Research and Development database for business R\&D expenditure; and EU-KLEMS and WORLD-KLEMS databases for the labour share.

79. The instruments in Section 5 rely on the financial deregulation index by Abiad et al. (2010). The information on non-performing loans in Subsection 6.3 is taken from the World Bank Global Financial Development database. The decompositions by type of borrower and lender in the same subsection use data from the BIS credit series and the OECD Economic Outlook database. The study of the role of external trade in Subsection 6.4 relies on data from the OECD Trade in Value Added (TiVA) database. 


\section{APPENDIX 2. CAPITAL SURCHARGES TO INTERNALISE PUBLIC GUARANTEES FOR TOO-BIG-TO-FAIL BANKS: A SIMPLE CALCULATION}

80. This appendix details the calculations behind the statement in Subsection 6.5 that a capital surcharge of roughly $13 \%$ of unweighted assets would be required to increase too-big-to-fail (TBTF) banks' funding cost by an amount equivalent to the estimated implicit subsidy that they receive from the public authorities. The TBTF subsidy creates risks of financial instability and capital misallocation. It often implies large contingent liabilities on the balance sheets of governments, central banks or both. While there are policy measures that can tackle the TBTF issue head-on (such as reducing banks' size and interconnectedness to alleviate the systemic effects of failure) or internalise the TBTF subsidy directly (such as systemic bank levies), an indirect way of internalising the subsidy is to impose a higher capital requirement on TBTF banks.

81. The cost to TBTF banks of a capital surcharge can be compared to the value of the TBTF subsidy in a simple model where the costs of equity and debt are assumed to remain constant. Although common, this assumption is very strong. By making banks safer, capital surcharges can be expected to reduce risks for debt and equity holders, which could translate into a lower expected return on equity and lower yield on newly issued debt. If this logic works unabatedly, which in particular requires no tax bias in favour of debt, changing banks' financing structure by imposing a capital surcharge will leave their funding cost unchanged, in line with the Modigliani and Miller (1958) theorem. To the extent that the logic behind the Modigliani-Miller theorem works in practice in response to TBTF capital surcharges, their cost to banks will be lower than estimated in the simple model that follows.

82. If $e$ denotes the rate of return on capital, $d$ the effective interest rate paid on debt, $x_{0}$ the leverage ratio comparing capital with total liabilities $L$ before regulation and $x_{1}$ the same leverage ratio afterwards, then a capital surcharge increases funding costs by $\left(x_{1}-x_{0}\right)(e-d) L$. The value of the subsidy is equal to the TBTF subsidy rate $s$ multiplied by the amount of debt after adjusting the capital surcharge: $\left(1-x_{1}\right) L$. Imposing on TBTF banks an extra funding cost equal to the value of the subsidy therefore means choosing $\left(x_{1}-x_{0}\right)$ such that:

$$
\left(x_{1}-x_{0}\right)(e-d) L=s\left(1-x_{1}\right) L .
$$

This equality condition simplifies in a straightforward manner as:

$$
\left(x_{1}-x_{0}\right)=\frac{s\left(1-x_{0}\right)}{e-d+s} \text {. }
$$

83. Public support derived from TBTF status is reckoned to be worth $1.3 \%$ of guaranteed liabilities, an estimate applicable to large European banks (Schich et al., 2014). While the methodology underlying this estimate makes use of information on the bank bond market, other liabilities, especially deposits, also benefit from mostly unfunded guarantees provided by the public authorities. Against this background, and for the sake of simplicity, the present calculation uses this estimate for the subsidy rate $s$ for bank liabilities other than capital. 
84. Estimates of banks' return on equity, $e$, effective interest rate paid on debt, $d$, and leverage ratio before regulation, $x_{0}$, are calculated using statistics reported in the last update of the OECD Bank Profitability Statistics database before its discontinuation (OECD, 2010). In line with the sample of large European banks underpinning Schich et al.'s (2014) assessment, these estimates have been calculated using OECD (2010) statistics for large commercial banks in Europe. The estimated leverage ratio before regulation, $x_{0}(3.6 \%)$, is an average calculated from 1999, when the database starts, to 2007, the last year before the financial crisis became full-blown. The parameters $e$ and $d$ for the cost of equity (12\%) and debt $(3.3 \%)$ are calculated over the same period. 


\section{BIBLIOGRAPHY}

Abiad, A., E. Detragiache and T. Tressel (2010), “A New Database of Financial Reforms", IMF Staff Papers, 75(2), pp. 281-302.

Admati, A. and M. Hellwig (2013), The Bankers' New Clothes: What's Wrong with Banking and What to Do about It, Princeton University Press, Princeton, New Jersey.

Ahrend, R., A. Goujard and C. Schwellnus (2012), "International Capital Mobility: Which Structural Policies Reduce Financial Fragility", OECD Economic Policy Papers, No. 2, OECD Publishing, Paris.

Angeles, L. (2015), "Credit Expansion and the Economy", Applied Economics Letters, 22(13), pp. 10641072 .

Angrist, J. D. and J.-S. Pischke (2009), Mostly Harmless Econometrics: An Empiricist's Companion, Princeton University Press, Princeton, New Jersey.

Arcand, J.-L., E. Berkes and U. Panizza (2012), “Too much Finance?”, IMF Working Papers, No. 12/161.

Arnold, J., A. Bassanini and S. Scarpetta (2011), "Solow or Lucas? Testing Speed of Convergence on a Panel of OECD Countries", Research in Economics, 65(2), pp. 110-123.

Barro, R. J. and J. W. Lee (2013), "A New Data Set of Educational Attainment in the World, 1950-2010", Journal of Development Economics, 104, pp. 184-198.

Basel Committee on Banking Supervision (2011), "Global Systemically Important Banks: Assessment Methodology and the Additional Loss Absorbency Requirement”, BIS, Basel.

Bassanini, A., S. Scarpetta and P. Hemmings (2001), "Economic Growth: The Role of Policies and Institutions: Panel Data Evidence from OECD Countries", OECD Economics Department Working Papers, No. 283, OECD Publishing, Paris.

Bazzi, S. and M. A. Clemens (2013), "Blunt Instruments: Avoiding Common Pitfalls in Identifying the Causes of Economic Growth", American Economic Journal: Macroeconomics, 5(2), pp. 152-186.

Beck, R., G. Georgiadis and R. Straub (2014), "The Finance and Growth Nexus Revisited", Economics Letters, 124(3), pp. 382-385.

Beck, T. (2009), "The Econometrics of Finance and Growth", in: T. C. Mills and K. Patterson (eds.), Palgrave Handbook of Econometrics: Vol. 2 - Applied Econometrics, Palgrave Macmillan, New York.

Beck, T. (2012), "The Role of Finance in Economic Development: Benefits, Risks, and Politics", in: D. C. Mueller (ed.), The Oxford Handbook of Capitalism, Oxford University Press, New York. 
Beck, T. and R. Levine (2002), "Industry Growth and Capital Allocation: Does Having a Market- or BankBased System Matter?", Journal of Financial Economics, 64(2), pp. 147-180.

Beck, T., R. Levine and N. Loayza (2000), "Finance and the Sources of Growth", Journal of Financial Economics, 58(1-2), pp. 261-300.

Bhide, A. (1993), "The Hidden Costs of Stock Market Liquidity”, Journal of Financial Economics, 34(1), pp. 31-51.

Black, S. E. and P. E. Strahan (2002), "Entrepreneurship and Bank Credit Availability", Journal of Finance, 57(6), pp. 2807-2833.

Blundell, R. and S. Bond (1998), "Initial Conditions and Moment Restrictions in Dynamic Panel Data Models”, Journal of Econometrics, 87(1), pp. 115-143.

Braun, M. and B. Larrain (2005), "Finance and the Business Cycle: International, Inter-Industry Evidence", Journal of Finance, 60(3), pp. 1097-1128.

Caselli, F., G. Esquivel and F. Lefort (1996), "Reopening the Convergence Debate: A New Look at CrossCountry Growth Empirics", Journal of Economic Growth, 1(3), pp. 363-389.

Cecchetti, S. G. and E. Kharroubi (2012), "Reassessing the Impact of Finance on Growth", BIS Working Papers, No. 381.

Cecchetti, S. G. and E. Kharroubi (2015), "Why Does Financial Sector Growth Crowd Out Real Economic Growth?”, BIS Working Papers, No. 490.

Cerra, V. and S. C. Saxena (2008), "Growth Dynamics: The Myth of Economic Recovery", American Economic Review, 98(1), pp. 439-457.

Čihák, M., A. Demirgüç-Kunt, E. Feyen and R. Levine (2012), "Benchmarking Financial Systems around the World”, World Bank Policy Research Working Papers, No. 6175.

Cournède, B., O. Denk and P. Hoeller (2015), "Finance and Inclusive Growth", OECD Economic Policy Papers, No. 14, OECD Publishing, Paris.

de Serres, A., S. Kobayakawa, T. Sløk and L. Vartia (2006), "Regulation of Financial Systems and Economic Growth in OECD Countries: An Empirical Analysis", OECD Journal: Economic Studies, 43, pp. 77-113.

Dembiermont, C., M. Drehmann and S. Muksakunratana (2013), "How Much Does the Private Sector Really Borrow? A New Database for Total Credit to the Private Non-Financial Sector", BIS Quarterly Review, March 2013, pp. 65-81.

Demirgüç-Kunt, A. and V. Maksimovic (2002), "Funding Growth in Bank-Based and Market-Based Financial Systems: Evidence from Firm-Level Data", Journal of Financial Economics, 65(3), pp. 337-363.

Denk, O. (2015), "Financial Sector Pay and Labour Income Inequality: Evidence from Europe", OECD Economics Department Working Papers, No. 1225, OECD Publishing, Paris. 
Denk, O., S. Schich and B. Cournède (2015), "Why Implicit Bank Debt Guarantees Matter: Some Empirical Evidence", OECD Journal: Financial Market Trends, 107, OECD Publishing, Paris.

Diamond, D. W. (1984), "Financial Intermediation and Delegated Monitoring", Review of Economic Studies, 51(3), pp. 393-414.

European Systemic Risk Board (2014), "Is Europe Overbanked?", Reports of the Advisory Scientific Committee, No. 4.

Federal Reserve Bank of New York (2013), Quarterly Report on Household Debt and Credit - Third Quarter 2013, New York.

Furceri, D. and A. Mourougane (2012), "The Effect of Financial Crises on Potential Output: New Empirical Evidence from OECD Countries”, Journal of Macroeconomics, 34(3), pp. 822-832.

Gambacorta, L., J. Yang and K. Tsatsaronis (2014), "Financial Structure and Growth", BIS Quarterly Review - March 2014, Bank for International Settlements.

Gennaioli, N., A. Shleifer and R. Vishny (2014), "Finance and the Preservation of Wealth", Quarterly Journal of Economics, (129)3, pp. 1221-1254.

Goldsmith, R. W. (1969), Financial Structure and Development, Yale University Press, New Haven, Connecticut.

Hellwig, M. (1991), "Banking, Financial Intermediation and Corporate Finance", in: A. Giovannini and C. Mayer (eds.), European Financial Integration, Cambridge University Press, Cambridge, UK.

Hsu, P.-H., X. Tian and Y. Xu (2014), "Financial Development and Innovation: Cross-Country Evidence", Journal of Financial Economics, 112(1), pp. 116-135.

Jayaratne, J. and P. E. Strahan (1996), "The Finance-Growth Nexus: Evidence from Bank Branch Deregulation", Quarterly Journal of Economics, 111(3), pp. 639-670.

King, R. G. and R. Levine (1993a), "Finance and Growth: Schumpeter Might Be Right", Quarterly Journal of Economics, 108(3), pp. 717-737.

King, R. G. and R. Levine (1993b), "Finance, Entrepreneurship, and Growth: Theory and Evidence", Journal of Monetary Economics, 32(3), pp. 513-542.

Laeven, L. and F. Valencia (2013), "Systemic Banking Crises Database”, IMF Economic Review, 61(2), pp. 225-270.

Langfield, S. and M. Pagano (2015), "Bank Bias in Europe: Effects on Systemic Risk and Growth", Economic Policy, forthcoming.

Law, S. H. and N. Singh (2014), “Does Too Much Finance Harm Economic Growth?”, Journal of Banking \& Finance, 41, pp. 36-44.

Leahy, M., S. Schich, G. Wehinger, F. Pelgrin and T. Thorgeirsson (2001), "Contributions of Financial Systems to Growth in OECD Countries", OECD Economics Department Working Papers, No. 280, OECD Publishing, Paris. 
Levine, R. (2002), “Bank-Based or Market-Based Financial Systems: Which Is Better?”, Journal of Financial Intermediation, 11(4), pp. 398-428.

Levine, R. (2005), "Finance and Growth: Theory and Evidence", in: P. Aghion and S. Durlauf (eds.), Handbook of Economic Growth, Elsevier, Philadelphia.

Levine, R., N. Loayza and T. Beck (2000), "Financial Intermediation and Growth: Causality and Causes", Journal of Monetary Economics, 46(1), pp. 31-77.

Liang, K.-Y. and S. L. Zeger (1986), "Longitudinal Data Analysis Using Generalized Linear Models", Biometrika, 73(1), pp. 13-22.

Mankiw, N. G., D. Romer and D. N. Weil (1992), "A Contribution to the Empirics of Economic Growth", Quarterly Journal of Economics, 107(2), pp. 407-437.

Modigliani, F. and M. H. Miller (1958), "The Cost of Capital, Corporation Finance and the Theory of Investment”, American Economic Review, 48(3), pp. 261-297.

OECD (2010), Bank Profitability: Financial Statements of Banks, OECD Publishing, Paris.

OECD (2014), OECD Economic Surveys: Turkey 2014, OECD Publishing, Paris.

Ollivaud, P. and D. Turner (2014), "The Effect of the Global Financial Crisis on OECD Potential Output", OECD Economics Department Working Papers, No. 1166, OECD Publishing, Paris.

Pagano, M. and G. Pica (2012), "Finance and Employment”, Economic Policy, 27(69), pp. 5-55.

Philippon, T. and A. Reshef (2013), "An International Look at the Growth of Modern Finance", Journal of Economic Perspectives, 27(2), pp. 73-96.

Rajan, R. G. (1992), "Insiders and Outsiders: The Choice between Informed and Arm's-Length Debt", Journal of Finance, 47(4), pp. 1367-1400.

Rajan, R. G. and L. Zingales (1998), "Financial Dependence and Growth", American Economic Review, 88(3), pp. 559-586.

Roodman, D. (2009), "How to Do xtabond2: An Introduction to Difference and System GMM in Stata", Stata Journal, 9(1), pp. 86-136.

Rousseau, P. L. and P. Wachtel (2011), "What is Happening to the Impact of Financial Deepening on Economic Growth?”, Economic Inquiry, 49(1), pp. 276-288.

Schich, S., M. Bijlsma and R. Mocking (2014), "Improving the Monitoring of the Value of Implicit Guarantees for Bank Debt", OECD Journal: Financial Market Trends, 106, OECD Publishing, Paris.

Schich, S. and S. Lindh (2012), "Implicit Guarantees for Bank Debt: Where Do We Stand?", OECD Journal: Financial Market Trends, 102, OECD Publishing, Paris.

Schularick, M. and A. M. Taylor (2012), "Credit Booms Gone Bust: Monetary Policy, Leverage Cycles, and Financial Crises, 1870-2008”, American Economic Review, 102(2), pp. 1029-1061. 
Stock, J. H., J. H. Wright and M. Yogo (2002), “A Survey of Weak Instruments and Weak Identification in Generalized Method of Moments", Journal of Business \& Economic Statistics, 20(4), pp. 518-529.

Sutherland, D., P. Hoeller, R. Merola and V. Ziemann (2012), "Debt and Macroeconomic Stability", OECD Economics Department Working Papers, No. 1003, OECD Publishing, Paris.

Tridico, P. (2013), "The Impact of the Economic Crisis on EU Labour Markets: A Comparative Perspective", International Labour Review, 152(2), pp. 175-190.

Ueda, K. and B. Weder di Mauro (2013), "Quantifying Structural Subsidy Values for Systemically Important Financial Institutions", Journal of Banking \& Finance, 37(10), pp. 3830-3842.

Windmeijer, F. (2005), "A Finite Sample Correction for the Variance of Linear Efficient Two-Step GMM Estimators", Journal of Econometrics, 126(1), pp. 25-51. 


\section{WORKING PAPERS}

The full series of Economics Department Working Papers can be consulted at www.oecd.org/eco/workingpapers.

1222. What impedes household investment in energy efficiency and renewable energy?

(May 2015) by Nadia Ameli and Nicola Brandt

1221. Recent trends in productivity in China - shift-share analysis of labour productivity growth and the evolution of the productivity gap

(May 2015) by Margit Molnar and Thomas Chalaux

1220. Assessing China's skills gap and inequalities in education

(May 2015) by Margit Molnar, Boqing Wang and Ruidong Gao

1219. Providing the right skills to all in China - from "made in China" to "created in China" (May 2015) by Margit Molnar and Vincent Koen

1218. Agricultural reforms and bridging the gap for rural China

(May 2015) by Ben Westmore

1217. A snapshot of China's service sector

(May 2015) by Margit Molnar and Wei Wang

1216. Does the post-crisis weakness of global trade solely reflect weak demand?

(May 2015) by Patrice Ollivaud and Cyrille Schwellnus

1215. Estonia: raising productivity and benefitting more from openness

(May 2015) by Andreas Kappeler

1214. Estonia: making the most of human capital

(May 2015) by Andrés Fuentes Hutfilter

1213. The Czech labour market: documenting structural change and remaining challenges

(May 2015) by Sónia Araújo and Petr Malecek

1212. Reforming the Slovak public sector

(April 2015) by Lilas Demmou and Robert Price

1211. Spurring growth in lagging regions in the Slovak Republic

(April 2015) by Lilas Demmou, Gabriel Machlica, Martin Haluš and Robert Menkyna

1210. Skill mismatch and public policy in OECD countries

(April 2015) by Müge Adalet McGowan and Dan Andrews

1209. Labour market mismatch and labour productivity: evidence from PIAAC data

(April 2015) by Müge Adalet McGowan and Dan Andrews

1208. Maintaining an efficient and equitable housing market in Belgium

(April 2015) by Sanne Zwart 
1207. Determinants of the low female labour force participation in India (April 2015) by Piritta Sorsa, Jan Mares, Mathilde Didier, Caio Guimaraes, Marie Rabate, Gen Tang and Annamaria Tuske

1206. Strengthening skill use and school-to-work transitions in the Czech Republic (April 2015) by Sónia Araújo and Petr Malecek

1205. Reforming the tax on immovable property: taking care of the unloved (April 2015) by Hansjörg Blöchliger

1204. Taxation and investment in Colombia (April 2015) by Sarah Perret and Bert Brys

1203. Efficiency and contestability in the Colombian banking system (April 2015) by Christian Daude and Julien Pascal

1202. Fiscal decentralisation in Colombia: new evidence regarding sustainability, risk sharing and "fiscal fatigue" (April 2015) by Guillaume Bousquet, Christian Daude and Christine de la Maisonneuve

1201. Effects of economic policies on microeconomic stability (April 2015) by Boris Cournède, Paula Garda and Volker Ziemann

1200. The 2013 update of the OECD's database on product market regulation - policy insights for $O E C D$ and non-OECD countries (April 2015) by Isabell Koske, Isabelle Wanner, Rosamaria Bitetti and Omar Barbiero

1199. Improving taxes and transfers in Australia (April 2015) by Philip Hemmings and Annamaria Tuske

1198. Federal-state relations in Australia (April 2015) by Vassiliki Koutsogeorgopoulou and Annamaria Tuske

1197. Sharing the fruits of growth with all Mexicans (April 2015) by Eduardo Olaberriá and Valéry Dugain

1196. What makes Mexicans happy?

(April 2015) by Valéry Dugain and Eduardo Olaberriá

1195. Improving the labour market integration of immigrants in Belgium (March 2015) by Álvaro Pina, Vincent Corluy and Gerlinde Verbist

1194. Raising the potential of the domestically oriented sector in Germany (March 2015) by André Eid and Andrés Hutfilter

1193. Improving transport infrastructure in Russia (March 2015) by Alexander Kolik, Artur Radziwill and Natalia Turdyeva

1192. Improving the business climate in Russia

(March 2015) by Arthur Radziwill and Yana Vaziakova 